\title{
Recent Advances in Biopolymeric Membranes towards the Removal of Emerging Organic Pollutants from Water
}

\author{
Feziwe B. Mamba ${ }^{1}$, Bhekani S. Mbuli ${ }^{2, *}$ and James Ramontja ${ }^{3, *(D)}$ \\ 1 Department of Chemical Sciences, Faculty of Science, University of Johannesburg, P.O. Box 17011, \\ Doornfontein, Johannesburg 2028, South Africa; feziwemamba@gmail.com \\ 2 DST/Mintek Nanotechnology Innovation Centre, University of Johannesburg, \\ Johannesburg 2028, South Africa \\ 3 Centre for Nanomaterials Science Research, University of Johannesburg, Johannesburg 2028, South Africa \\ * Correspondence: bhekanimbuli@yahoo.com or bmbuli@uj.ac.za (B.S.M.); jamesr@uj.ac.za (J.R.)
}

Citation: Mamba, F.B.; Mbuli, B.S.; Ramontja, J. Recent Advances in Biopolymeric Membranes towards the Removal of Emerging Organic Pollutants from Water. Membranes 2021, 11, 798. https://doi.org/ 10.3390/membranes11110798

Academic Editor: Alfredo Cassano

Received: 14 September 2021

Accepted: 13 October 2021

Published: 20 October 2021

Publisher's Note: MDPI stays neutral with regard to jurisdictional claims in published maps and institutional affiliations.

Copyright: (c) 2021 by the authors. Licensee MDPI, Basel, Switzerland. This article is an open access article distributed under the terms and conditions of the Creative Commons Attribution (CC BY) license (https:// creativecommons.org/licenses/by/ $4.0 /)$.

\begin{abstract}
Herein, this paper details a comprehensive review on the biopolymeric membrane applications in micropollutants' removal from wastewater. As such, the implications of utilising non-biodegradable membrane materials are outlined. In comparison, considerations on the concept of utilising nanostructured biodegradable polymeric membranes are also outlined. Such biodegradable polymers under considerations include biopolymers-derived cellulose and carrageenan. The advantages of these biopolymer materials include renewability, biocompatibility, biodegradability, and cost-effectiveness when compared to non-biodegradable polymers. The modifications of the biopolymeric membranes were also deliberated in detail. This included the utilisation of cellulose as matrix support for nanomaterials. Furthermore, attention towards the recent advances on using nanofillers towards the stabilisation and enhancement of biopolymeric membrane performances towards organic contaminants removal. It was noted that most of the biopolymeric membrane applications focused on organic dyes (methyl blue, Congo red, azo dyes), crude oil, hexane, and pharmaceutical chemicals such as tetracycline. However, more studies should be dedicated towards emerging pollutants such as micropollutants. The biopolymeric membrane performances such as rejection capabilities, fouling resistance, and water permeability properties were also outlined.
\end{abstract}

Keywords: membrane fouling; micropollutants; water treatment; separation mechanisms; biodegradable

\section{Introduction}

The conventional wastewater treatment plants (WWTPs) have demonstrated to have limited effectiveness against the removal of these CECs. In such cases, the treated WWTP effluents tend to contain the organic micropollutant contaminants [1]. For example, Nam et al. [1] reported that nonylphenol, an endocrine disruptor, had limited removal efficiency, ranging between 53\% and 55\%, within WWTPs; consequently, the nonylphenol is detected in treated WWTP effluents [1]. Emerging contaminants have been overlooked for the longest time and limited studies have been conducted on their detection and remediation as emerging contaminant threats $[2,3]$. This is especially because few researchers are concerned about the adverse effects of micropollutants. Therefore, novel technologies dedicated to the remediation of the organic micropollutants should be developed [2].

Hence, in this review, membrane technology is discussed to cater for its challenges and success in the removal capacity of organic micropollutants from water. Notably, secondary pollution occurs because of the disposal of the remnants of membranes and/or adsorbents after use. Unfortunately, these plastics that remain further pollute the available water suitable for drinking. This occurs because the materials being used to treat water are disposed into landfills and may further pollute groundwater. As such, most polymeric membranes are not degradable and turn out to have extended half-life and this may be detrimental to the environment. However, secondary pollution can be eliminated by using biodegradable 
material for micropollutant remediation. Herein, this review paper discusses the utilization for biopolymers in membrane technology applications. Therefore, this paper comprehensively reviews the recently reported membrane filtration-based techniques specifically dedicated towards organic micropollutants' water treatment. Fundamentally, implementation drawbacks of biopolymeric membranes in water purification are discussed. Further to this, strategies that can improve biopolymeric membrane properties are discussed.

\subsection{Biopolymers: Properties and Applications}

Biopolymers are polymers that are relatively sourced from living organisms, such as plants and microbes, rather than from petroleum [4]. They are classified as synthetic and natural biopolymers [5]. The synthetic biopolymers are polymers that can either be modified from natural polymers or chemically synthesized from synthetic monomers. For example, synthetic biopolymers include polylactic acid (PLA), polycaprolactone (PCL), and polyvinyl alcohol (PVA). On the other hand, natural biopolymers are sourced from natural sources $[5,6]$. These naturally sourced biopolymers include cellulose, starch, chitosan [5-7], collagen, fibrinogen [5,6], chitin, alginate, and carrageenan, among others [7]. Among these, chitosan and cellulose are the most readily available biopolymers in nature. Carrageenan, which is a seaweed, is divided into three derivatives, i.e., kappa-carrageenan, iota-carrageenan, and lambda-carrageenan, which is determined by the degree of sulfation. Starch is mostly obtained from stalks, roots, and crop seeds [7]. Similarly, cellulose is sourced from plants, fungi, bacteria, and algae [8]. Cellulose has been extracted from various agricultural waste materials such as pomelo [9], banana peels, corn stalks, vegetable waste, wood chips, grain husks, stubble [10], peels from mango, cucumber [11], oranges [11,12], banana [10,11], bagasse, nut shells, willow branches, rice husks, and straw [12].

Biopolymers are hydrophilic, and this enhances membrane-fouling resistance and water permeability when utilised as membranes for water treatment $[8,13]$. The hydrophilic functional groups preferentially enable the formation of a thin layer of water on membranes' surfaces. This preferential formation on the hydrophilic membrane surfaces prevents the deposition of foulants. Thus, this phenomenon reduces membrane fouling [13]. Furthermore, cellulose is highly hydrophilic, with contact angles ranging between $20^{\circ}$ and $30^{\circ}$. Fundamentally, the hydrophilic properties of the cellulose are brought about by the presence of hydroxyl functional groups. These hydroxyl functional groups form hydrogen bonds with water, and this enables preferential attachment of water molecules that promote water permeability [8]. Furthermore, biopolymers are highly considered because of their ability to decompose once disposed in landfills [5]. Fortunately, there are no harmful by-products that are released during the biodegradation of biopolymers. The known by-products include humus, carbon dioxide, biomass, and methane. Thus, it becomes advisable to utilize biopolymers in water treatment applications [10].

\subsection{The Use of Biopolymers in Membrane Techniques}

Various researchers have developed several approaches towards the remediation of wastewater treatment. These techniques include adsorption, filtration, membrane technology, and advance oxidation methods such as ozonation, photocatalysis [14,15], and biodegradation [15]. However, these technologies have to be highly effective, efficient, and economical [16]. Membranes are preferred over conventional water treatment processes, such as flocculation, adsorption, and coagulation, among others, because membranes have demonstrated effective wastewater purification and they pose limited hazard to the environment [17]. During separation, a membrane acts as a barrier to selectively allow water molecules to pass through and prevent the passage of impurities [18]. A wide variety of polymers have been used in the fabrication of non-biodegradable polymeric membranes. Notably, most commercial membranes are synthesized and fabricated using non-biodegradable materials. The commonly used non-biodegradable polymers include polyvinylidene fluoride (PVDF) [13,19-21], polysulfone (PSf), polyethersulfone 
(PES) [19-22], polyphenylsulfone [22], polypropylene [23], polyvinyl alcohol, polystyrene, and poly(1,5-diaminonaphthalene), among others [24]. Most of these synthetic polymers used in membrane production are non-biodegradable and possess hydrophobic properties. Regrettably, the hydrophobicity of these membranes renders them susceptible to membrane fouling $[13,19,22]$. Unfortunately, once the micropollutant foulants are deposited on the membrane surfaces, the water permeability is compromised. Consequently, this increases the need for frequent membrane cleaning, thereby increasing maintenance costs of the membrane system $[13,19,22,25]$.

Notably, fouling increases operational costs because of constant membrane cleaning, usually accomplished through chemical washing. Consequently, the quality of the membrane and lifespan get reduced significantly $[18,25]$. In contrast, biopolymers are renewable, sustainable, biodegradable, cost effective, compostable, eco-friendly, non-toxic, biocompatible, and hydrophilic [26-31]. Furthermore, biopolymers are known to be hydrophilic, and hydrophilic materials significantly improve the rejection capacity and efficiency of biopolymeric membranes [26,27,32-34]. Thus, biopolymers can substitute the potentially toxic and nonbiodegradable polymers used as an alternative in membrane fabrication since they are environmentally friendly $[26,27,32]$.

It is highly desirable that methods to remove and neutralize organic micropollutants be efficiently developed [35]. For example, membrane filtration technologies have been considered because of their inherent simplicity and efficiency, even at high pollutant concentrations. Furthermore, they have minimal solid waste generation. In addition, membranes tend to eliminate virtually all types of dyes, salts, and mineral derivatives [36]. Therefore, membrane technology has promising capacity towards organic pollution treatment [37]. There are different membrane technologies, and these are ultrafiltration (UF), nanofiltration (NF), reverse osmosis (RO), and forward osmosis (FO) membranes. These membrane technologies can remove numerous micropollutant contaminants. For instance, nanofiltration and reverse osmosis membranes are commonly utilized to treat micropollutants and they have demonstrated some level of efficiency towards micropollutant remediation [35,38]. For example, NF membranes have been used for the retention of multivalent ions and organic compounds under relatively low operation pressure [37]. On the other hand, $\mathrm{RO}$ membranes can remove monovalent salts and micropollutants from water, even at low concentrations.

Polymeric membranes are the commonly utilized materials during membrane fabrication because of their ease to work with. Consequently, membrane fabrication processing parameters are formulated and implemented to accomplish maximum water permeability and micropollutant rejection performances [39]. As such, the removal efficiencies of these polymeric membranes can be experimentally controlled through adjusted contact time parameters, type of water sources, concentrations of micropollutants, and building components of the membranes [2].

These non-renewable and non-biodegradable polymers can be detrimental to the environment over time. This is because after their service half-life, they are usually discarded onto landfills and sometimes find their way into the aquatic environment. In some case, these materials are burned, thereby leading to secondary pollution such as global warming [19,40]. As such, environmental pollution and landfills are currently stretched beyond capacity. Thus, adding non-biodegradable membrane materials on top of the environmental pollution pressure becomes detrimental. Therefore, there is a need to develop completely biodegradable materials that can easily degrade completely after use, thereby preventing secondary pollution. Natural biopolymers such as starch, pullulan, cellulose, chitosan, alginate, and proteins have been used in water purification [6]. Such polymers have been sourced from waste material and converted into reusable materials such as cellulose, thus reducing waste material [10]. 


\subsection{Water Micropollutants and Their Impact on Human and Animal Health}

One challenge in water treatment of micropollutant-contaminated water is the change of chemical structures into new chemical moieties, which might be even more toxic than the parent organic compound [14]. Furthermore, the organic micropollutant contaminants in water tend to resist degradation; hence, such pollutants turn out to be persistent in water. Consequently, these chemicals bioaccumulate in adipose tissues of aquatic animals. This is, therefore, detrimental to the aquatic life's health [15].

Organic micropollutants are organic compounds that are toxic to the environment within water bodies, even at low concentrations, ranging between $\mu \mathrm{g} / \mathrm{L}$ and $\mathrm{ng} / \mathrm{L}$ levels $[41,42]$. Prevalent micropollutants' contamination such as polyaromatic hydrocarbons, antibiotics, pesticides, contraceptive medicines, and personal care products have been deposited into freshwater sources, thus leading to their accumulation in water bodies [41]. Some of the organic pollutants are released from agricultural activities, wastewater discharge from industries or households, accidental chemical spills, and oil spillage [41,43]. Notably, these include pesticides, pharmaceuticals, cosmetics, flame retardants, perfumes, waterproofing agents, plasticizers, and insulating foams, among others $[42,44,45]$. The commonly detected pharmaceuticals are antibiotics, antidepressant, antiepileptic, anti-inflammatory, and antiretroviral drugs [2,44]. Furthermore, these organic pollutants are known to be hazardous and noxious substances to the environment such as aquatic life and terrestrial animals dependent on those water body systems [41,43]. Due to such water pollution, the scarcity of clean and safe drinking water from natural sources remains on the rise [41,46].

Unfortunately, even at low concentrations, organic micropollutants have been found to be detrimental to aquatic animals and human beings, as illustrated in Figure 1 [41]. For example, human beings' exposure to pesticides such as organophosphates leads to challenges such as cognitive defects, cancer, and mutagenic complications [45,47]. Furthermore, elongated exposure to atrazine can inhibit androgenic hormone-related development, thus negatively affecting fertility in men and increasing chances of breast cancer in women [41].

Other conditions related to elongated exposure to organic micropollutants include skin blisters, respiratory challenges, and eye burns, and extreme cases may result in fatigue, lung problems, immune system damage, and cancer [48]. Furthermore, unregulated consumption of hormones can lead to the decrease of male sperm count. This may also upsurge cases of testicular, prostate, ovarian, and breast cancer, and effectively increase occurrences of reproductive malfunctions in human beings. Notably, endocrine disruption, genetic make-up damage, resistance in pathogenic bacteria, and aquatic toxicity are also associated with organic micro-pollution challenges [46,49].

Additionally, the development of bacterial resistance makes common infections, minor injuries, and routine operations riskier due to unmonitored consumption of antibiotics in drinking water, another concern to health systems [45]. Furthermore, long exposure of organisms to the organic micropollutants can affect the health of aquatic life such as the change in behavior of fish, which tends to affect their aggression, reproduction, and feeding activities [50].

As industries are being developed and their products' demand remains high, there is an increased usage of organic compounds, which leads to the high demand of water purification and treatment technologies. As it is, the increased utilization of organic products such as pharmaceuticals and pesticides has resulted in the reduction of clean water supplies for communities [52]. Furthermore, these contaminants of emerging concerns (CECs) tend to find their way into water systems $[1,53,54]$. As such, the most abundant agricultural contaminants include pesticides and herbicides such as atrazine, endosulfan cyanazine, and metribuzin. Notably, industries usually release these chemicals, such as methyl-tert-butyl-ether, and aromatics, such as benzene, toluene, dichlorobenzenes, and xylenes. Furthermore, personal care products that find their way into the water systems include caffeine, trimethoprim, sulfamethoxazole, carbamazepine, and diclofenac [53]. 


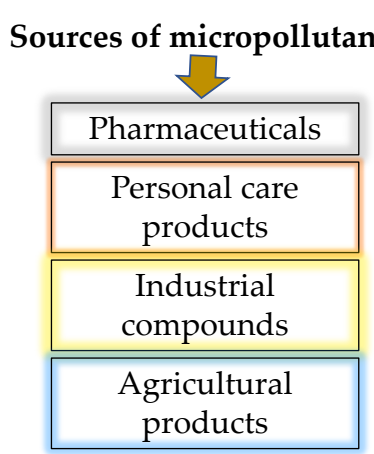

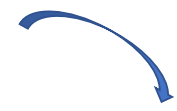

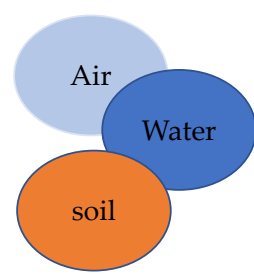

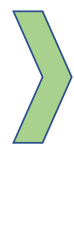

1. Cancer

2. Fertility issues

3. Immune system problems

4. Skin problems

5. Bacterial resistance

Figure 1. Some of the sources of micropollutants and their effects on humans and animals, as adapted from Vasilachi et al. [51].

These organic micropollutant contaminants find their way into water systems via various routes such as sewage treatment plants, human excretion [50], disposal of unused and expired pharmaceuticals, and agricultural pesticides $[1,50]$. In addition, the pollutants can also pass through drainage systems [1]. These micropollutants accumulate over time and are being progressively detected in water systems $[1,54]$. The sources of micropollutants and the various ways in which micropollutants find their ways into the water system are summarized in Figure 2.

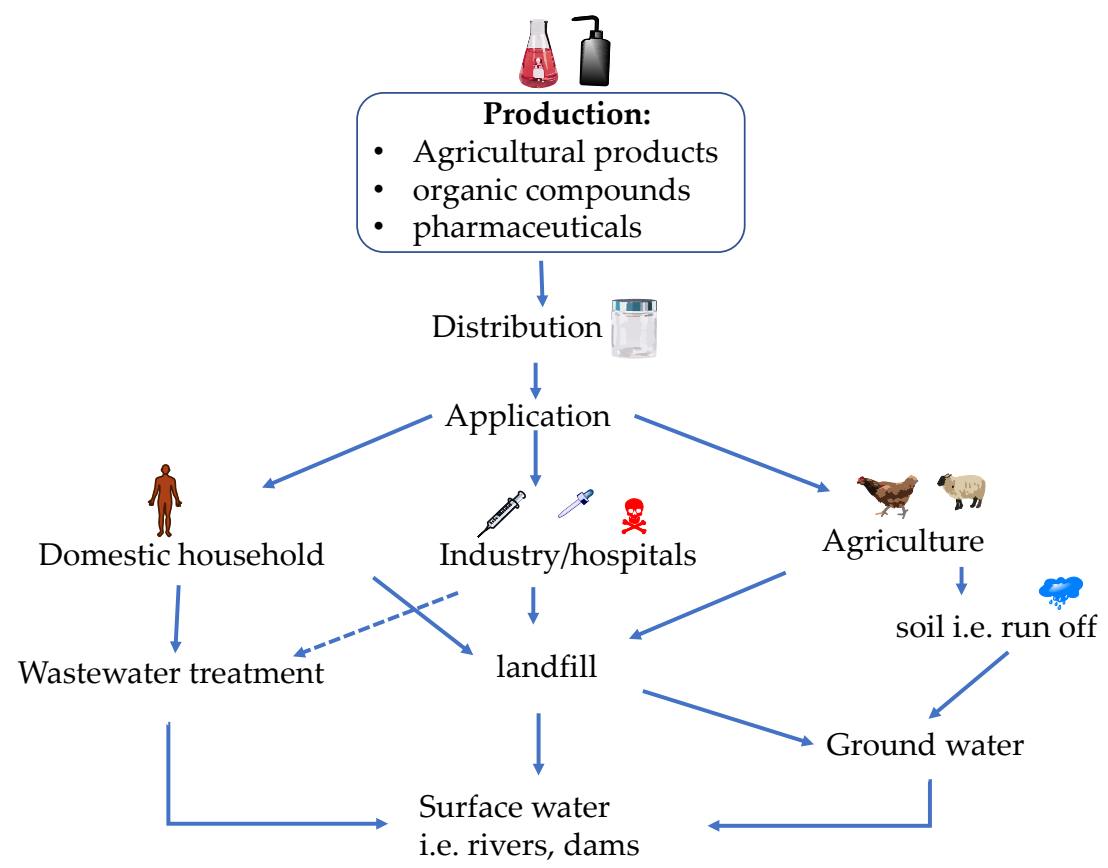

Figure 2. A path of micropollutants from production to drinking water, as adapted from Kanaujiya et. al. and Kümmerer et.al., respectively [55,56].

\subsection{Policy Frameworks and Guidelines for Water Treatment in South Africa}

Commercially, the predominantly utilized polymeric membranes are non-biodegradable for storage and water treatment. Regrettably, these plastic membranes are characterized by long half-lives and barely degrade completely over time. Instead, these non-biodegradable polymeric membranes are broken down into microplastics $(0.1 \mu \mathrm{m}-5 \mathrm{~mm})$ via various chemical and mechanical paths $[57,58]$. Unfortunately, these microplastics become an environmental concern as they persist on land and water systems, thereby causing secondary pollution.

South Africa and the rest of the world are currently struggling with these plastics polluting the environment. Notably, South Africa is among the leading contributors towards plastic pollution [59]. Therefore, using non-biodegradable membranes exacerbates this 
pollution problem. Hence, there is a need to eradicate this problem by seeking degradable membrane material that can easily be disposed and degrade after use. However, these biodegradable materials should be strong enough to complete the water treatment life cycle and effectively treat water. In most cases, researchers avoid using biodegradable materials because of mechanical strength concerns.

These microplastics have negative impacts on the environment and are harmful towards aquatic life. For example, microplastics have been reported to negatively impact marine life such as mussels in Cape Town, South Africa, as reported by Sparks et al. [57]. Therefore, relevant policies to address this plastic pollution challenge should be formulated, updated, implemented, and enforced to accommodate emerging micropollutants.

Remarkably, there are policy frameworks that have been established to control the level of pollution around the world, more especially in South Africa. For instance, the South African Water Guidelines and World Health Organization (WHO) have placed the atrazine detection limit concentration in water at $0.1 \mu \mathrm{g} / \mathrm{L}$ [60]. In other words, this implies that once the atrazine is above the limit, the contaminated water is regarded as unsuitable for human use as this may cause detrimental health challenges. Therefore, this calls for better water treatment technologies to address these contamination levels. However, such treatment technologies should be sustainable and avoid causing secondary pollution in the environment. This can be accomplished by adopting biopolymeric materials.

It is the United Nations' and African Union's goal to ensure that clean water and sanitation is provided for all $[61,62]$. Therefore, to meet the United Nation's Sustainable Development Goal Number (SDG) 6 and corresponding Africa Union's (AU) Agenda 2063 aspirations of providing clean water and sanitation for all, the South African Government established water contamination regulations that, when adhered to, can effectively prevent water pollution [62]. Such guidelines enable South African industrial activities to be regulated, to obtain an effluent discharge permit before releasing water into water systems. Failure to comply to such conditions of the permit can lead to penalties that include financial fines and subsequent withdrawal of operation permits [62,63].

Unfortunately, with all these policies and the challenges that are addressing the micropollutant levels, there are limited regulations that control the material used to treat water pollution. This includes addressing microplastics and possible secondary pollution brought about by using plastics/polymeric membranes to treat wastewater. As such, these regulations are not fully standardized, synchronized, and structured. Furthermore, the utilization of biopolymeric and degradable materials remains insufficiently encouraged by the South African government.

The South African government, through the Department of Environmental Affairs, is allowing plastic manufacturers to continue producing plastics with a minimum thickness of 24 microns, more especially for storage applications and purposes. Consequently, these plastics are highly produced for public use, even though it is at a price. Since the plastic price is significantly small (i.e., between R0.25-R0.80 per plastic bag), the public is still using these plastics ungoverned; hence, the uncontrollable plastic waste $[64,65]$. This clearly demonstrates that the plastics pollution challenge will not be addressed if researchers and innovators are not compelled to urgently consider biodegradable polymeric plastics as an option to explore for applications such as storage and water treatment, among others. Therefore, to fully realize environmentally friendly and sustainable water treatment, considerations should be made towards adopting biodegradable materials for water treatment applications. As such, the accompanying and enabling policies towards using biodegradable polymeric materials should be considered, formulated, and implemented to protect the environment. Consequently, creating these biopolymeric-biased policies can help South Africa realize the AU's Agenda 2063 and UN's SDGs.

\section{Polymeric Membranes in Water Treatment}

Membranes can either be polymeric or ceramic $[21,52,66]$. Notably, ceramic membranes are made from materials such as aluminum oxide $\left(\mathrm{Al}_{2} \mathrm{O}_{3}\right)$ [52]. Ceramic membranes 
are known to possess excellent mechanical and thermal properties and possess significant chemical stability. In addition, ceramic membranes possess superior fouling resistance that can lead to extended membrane longevity [67]. Thus, such membranes can withstand the strong oxidizing agents and can therefore be utilized in large organic materials such as dyes' removal applications [68]. Nevertheless, ceramic membranes have lower retention capacity on the removal of smaller organic materials [54,67]. This is because ceramic membranes have larger pores. Hence, ceramic membranes tend to limitedly retain micropollutants [54]. To this end, polymeric membranes are adopted to remove even small organic pollutants, including emerging micropollutants.

Polymeric membranes are advantageous over ceramic membranes because of their affordability and pollutant removal effectiveness [21,52]. Notably, polymeric membranes are known to be flexible. Thus, polymeric membranes can easily be fabricated for varied water treatment applications and environments. In addition, the polymeric membrane pore sizes are tunable when compared to ceramic membranes. Hence, the polymeric membranes can be applied in various industrial treatment applications towards the removal of smaller ions and trace elements from water [21,52]. Different polymeric membrane types can be used for water pollution filtration. This includes nanofiltration membranes that are applied in the filtration of brackish water, desalination, wastewater, and food industrial water treatments. Nanofiltration membranes are primarily used for the separation of divalent salts, heavy metals, and organic micropollutant molecules [33]. Reverse osmosis membranes, on the other hand, can remove monovalent salts from water. Ultrafiltration membranes can remove large organic molecules from water [69].

Polymeric membranes are mainly poor in temperature and chemical resistance compared to ceramic membranes and this interferes with the operational lifespan [52,70]. Thus, polymeric membranes with high chemical and thermal stability need to be developed to increase their usability under extreme conditions [70]. Pulido et al. [70] exhibited that pristine poly(oxindolebiphenylylene) membranes are chemically instable. Hence, crosslinkers were introduced to improve the stability of these membranes. The crosslinkers used for modification were 1-bromo-octane, 8-dibromo-octane, 1,4-di-bromo-butane, 1,4-diiodo-butane, 1,4-dibromo-2,3-butane-dione, $\alpha, \alpha^{\prime}$-dibromo-p-xylene, and 1,5-dibromo1,1,2,2,5,5-hexa-fluro-pentane. After crosslinking poly(oxindolebiphenylylene) with the different crosslinkers, the membranes were found to be stable against chemicals such as dimethyl sulfoxide (DMSO), N-methyl-2-pyrrolidone (NMP), dimethylformamide (DMF), and dimethylacetamide (DMA). Furthermore, Ba et al. [71] achieved chemically stable P84 copolyimide membranes during salt separation, either under acidic or basic conditions (i.e., $2 \leq \mathrm{pH} \leq 10$ ). These P84 copolyimide membranes were also stable against various organic solvents because of the imine functionality from the poly-ethylenimine.

The most common limitation of polymeric membranes is membrane fouling [23,72], as illustrated in Figure 3. During membrane fouling, a bridge (cake layer) is formed by organic and inorganic particles that turn to close the membrane pores. Subsequently, as the water sample flows through or across the membrane matrix, the foulants turn to be deposited onto the membrane surface and are sometimes trapped within the membrane pores. Consequently, these membrane pores turn to collect foulants until saturated, thereby forming a cake layer [21,73]. In addition, membrane fouling can also be caused by microorganism growth on membrane surfaces, also referred to as biofouling. Biofouling tends to grow on the surface of the membrane and subsequently formulates biofilm fouling $[21,72,73]$.

Membrane fouling reduces water permeability in membranes [74]. Subsequently, the fouled membranes require high pressure to enable water to pass through the membrane's matrix. Consequently, higher energy consumption is needed to enable the filtration process. On another hand, fouling delays filtration processes on operational membranes because of the sophisticated, frequent, and lengthy cleaning protocols. Fundamentally, this causes the use of the membranes to become more expensive. Most importantly, the membranes' structural and tensile strength integrity turn out to be negatively impacted. Subsequently, this operational expenditure becomes costly because of the frequent replacement measures [23,74]. 


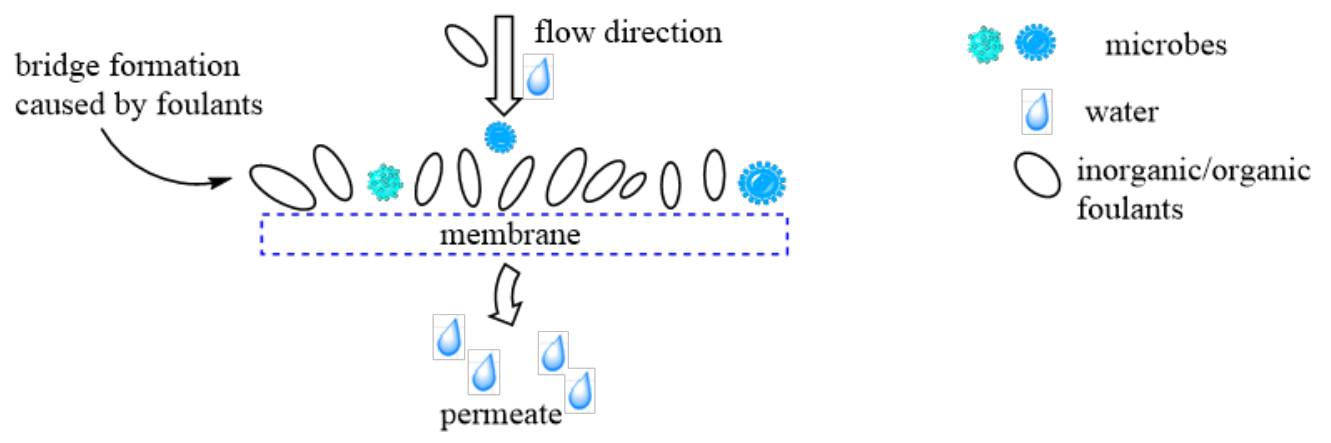

Figure 3. Membrane fouling mechanism during filtration [21].

The hydrophilicity of membrane materials contributes significantly towards membrane antifouling properties. Notably, higher membrane hydrophilicity may prevent foulants' deposits on membrane surfaces [21,73]. Other factors that affect the fouling of the membrane include the size of pollutants against membrane pores, shapes of pollutant particles in water samples, membrane's porosity, and membrane surface's functionality and charge [73]. As such, Katsoufidou et al. [74] demonstrated the fouling phenomenon by using sodium alginate. In this case, the researchers attributed the fouling of membranes because of calcium ions' adsorptive binding to the polysaccharide functional groups. This resulted in cake development on the membrane surface [74]. Unfortunately, this cake layer ought to be cleaned constantly to regain the filtration efficiency of the membrane.

Lee et al. [72] demonstrated salt cleaning and osmotic back-wash studies on calciumbridged, organic-fouled commercial flat sheet polyamide/polysulfone NF membranes. This was aimed at demonstrating cleaning possibilities of both techniques. The research study demonstrated that salt cleaning and osmotic backwash effectively cleaned the calciumbridged, organic-fouled membranes. However, the osmotic backwash cleaning method had higher cleaning efficiency [72]. Even though the membranes can be cleaned, it still becomes an extra requirement that turns out to be costly and compromises the lifespan of the membranes. Hence, developing sustainable self-cleaning and antifouling membranes should be developed.

\subsection{Removal of Emerging Organic Pollutants with Non-Biodegradable Polymers}

Since these synthetic polymers are predominantly hydrophobic, there is always a need to modify with hydrophilic materials. In some cases, these synthetic polymers are blended with biopolymers, such as hydrogels, chitin, cyclodextrins, and nanoparticles, to introduce hydrophilicity, thereby improving water permeability and fouling resistance properties. For instance, in an attempt to increase the membrane hydrophilicity, graphene oxide (GO) nanocomposites have been explored. For example, Leaper et al. [75] fabricated PVDF membranes incorporated with superhydrophobic polyhedral oligomeric silsesquioxane with graphene oxide (POSS-rGO). Consequently, this hybrid POSS-rGO/PVDF membrane rendered stable water permeability and rejection as compared to the pristine PVDF membranes. Similarly, Nawaz et al. [76] incorporated polyaniline-GO into PVDF membranes. This resulted in improved hydrophilicity, which subsequently enhanced the pure water flux and antifouling properties and increased dye rejection of $95 \%$ for methyl orange and $98 \%$ for allura red compared to pure PVDF with a dye rejection of less than $30 \%$ of both dyes. Similarly, Vatanpour et al. [77] incorporated nitrogen-doped GO into PES membranes to enhance the membrane's porosity, hydrophilicity, and their ability to experience hydrogen bonding during water filtration, hence, an improved rejection capacity of $91.1-95.6 \%$ as compared to the bare PES, which rejected $88.6 \%$ of Reactive Red 195 dye.

On the other hand, nanoparticles such as zirconium, metal organic frameworks, and faujasite have been used to improve the membrane hydrophilicity. For instance, Abdulkarem et al. [78] incorporated zirconium phosphate nanoparticles to improve the membrane hydrophilicity and water permeation. Dehghankar et al. [79] incorporated 
zirconium 1,4-dicarboxybenzene (UiO-66) and chromium (III) terephthalate (MIL-101) metal-organic frameworks (MOFs) and faujasite (FAU) zeolite nanocrystals into PVDF membranes. Consequently, this influenced the hydrophilic nature of the modified membranes, as demonstrated by the low water contact angles reported. Additionally, the porosity of the composite membrane was improved. The produced composite membranes had porosity $\%$ of $65-80 \%$, whereas the neat membrane's porosity was $65 \%$. Palygorskitechitin (PAL-CH) nanomaterials were incorporated by Mamah et al. [80] onto polyamide thin film composite membranes. Mutharasi et al. [81] incorporated Co-Al layered double hydroxide (LDH) into polysulfone membranes via coating.

In an attempt to enhance the selectivity of the PVDF, Altintas et al. [49] functionalized molecularly imprinted polymers with nanoparticles. As a result, the modified membranes exhibited $99.6 \%$ uptake capacity of $60.39 \mathrm{ng} / \mathrm{cm}^{2}$ for metoprolol, $94.7 \%$ uptake capacity of $45.09 \mathrm{ng} / \mathrm{cm}^{2}$ for diclofenac, and $42.6 \%$ uptake capacity of $16.9 \mathrm{ng} / \mathrm{cm}^{2}$ for vancomycin. On the other hand, Balta et al. [82] demonstrated that the addition of zinc oxide ( $\mathrm{ZnO})$ nanoparticles into PES polymeric membranes enhanced the membrane's hydrophilicity. Furthermore, the PES/ZnO membranes demonstrated better water permeabilities and dye rejection when compared with neat PES membrane. This was attributed to the increased hydrophilicity of the $\mathrm{ZnO}$-modified membranes.

$\mathrm{Li}$ et al. [83] illustrated that the addition of titanium dioxide $\left(\mathrm{TiO}_{2}\right)$ nanoparticles onto PES membranes increased their hydrophilicity. As such, the researchers reported that the addition of the $\mathrm{TiO}_{2}$ nanoparticles augmented the hydrophilic properties of the membranes, as the formation of the pores. Such nanoparticle-induced properties enhanced the water permeability performances of the modified composite membranes. The effect of $\mathrm{TiO}_{2}$ nanoparticle sizes on the performance of PVDF membranes was also investigated by $\mathrm{Cao}$ et al. [84]. These researchers demonstrated that $\mathrm{TiO}_{2}$ nanoparticles with smaller radii introduced better the antifouling property onto the PVDF membranes. Consequently, the small-sized $\mathrm{TiO}_{2}$ nanoparticles onto PVDF membranes had smaller mean pore sizes and limited roughness properties on the membrane surfaces.

All these modified synthetic membranes have demonstrated superior water permeation and fouling resistance properties. Notably, the modifying and blending of synthetic polymers for water treatment applications significantly improves performance properties. However, their disposal after use and potential secondary pollution remains a challenge as such is compounding the already difficult plastics' challenge the rest of the world is dealing with. Thus, considerations on exclusively utilizing biopolymers for water treatment applications should be made.

\subsection{Environmental Impact of Synthetic Polymers}

Non-biodegradable polymers have been used for water filtration, owing to their extreme chemical and thermal stability. However, their implementation can be detrimental to the environment [23]. For instance, during the synthesis of the polymers, the reagents are not completely reacted, such as styrene, caprolactone, bisphenol-A, acrylics, methacrylics, styrene, and vinyl acetate catalysts. This is due to interfering side reactions such as transesterification and ester/ester exchange. Hence, the conversion of the monomers into polymeric structures is often not $100 \%$ [85]. Consequently, these unreacted monomers may further pollute the environment [23]. Non-biodegradable polymers tend to break down into their building blocks' monomers that might be toxic to the environment. For instance, polycarbonate polymers can degrade into bisphenol-A (BPA) when exposed to salty aquatic environments [86]. Unfortunately, the BPA is associated with cancer in humans as a threat to human health [19]. Furthermore, once polymeric membranes have been utilized, they are discarded and disposed onto landfills, and may also pollute water body systems. However, since the membranes are non-biodegradable, they tend to persistently break down into smaller, environmentally toxic monomers when exposed to ultraviolet (UV) radiation due to sunlight [87]. 
The removal of the broken pieces of synthetic polymers from both the land and water is tedious and expensive [88]. Furthermore, the broken, smaller pieces can be mistaken for food by aquatic animals $[87,88]$. As much as recycling plastic regulations are established in South Africa, unfortunately these regulations are continually challenged. This is because of the limited plastic waste recycling infrastructure, and the plastics eventually pollute the environment [19]. In addition, the plastic waste that remains unrecycled ends up incinerated, and approximately $2.8 \mathrm{~kg}$ of carbon dioxide is released when $1 \mathrm{~kg}$ of plastic waste is burned. Other gases that are released during incineration include carbon monoxide and nitrogen oxide, and these are highly toxic to the environment [29].

Most researchers predominantly consider synthetic polymers for membrane technology suitable for water treatment applications. This is because synthetic polymers have significant chemical resistance, tensile strength, mechanical strength, and flexibility properties when compared to natural biopolymers [10,89]. However, due to their chemical resistance, these synthetic polymers degrade much more slowly and persist in the environment over an elongated period of time [89]. Consequently, some researchers have decided to blend synthetic polymers with natural polymers. Nonetheless, this does not result in completely biodegradable material.

For example, Kumar et al. [90] blended cellulose acetate with polyphenylsulfone (PPSU) membranes. Consequently, because of the resultant enhanced hydrophilicity and porosity of the membranes, their water permeability and antifouling properties were improved. In addition, Alam et al. [13] incorporated carrageenan ( $\mathrm{kCg}$ ) into PVDF membranes. The $\mathrm{kCg}$ concentration ranged between $0.5 \mathrm{wt} \%$ and $2.0 \mathrm{wt} \%$. Notably, the addition of the $\mathrm{kCg}$ biopolymer increased the porosity and hydrophilicity of the modified membranes. Consequently, this positively influenced the modified membrane's water permeability. Therefore, considering the variety of challenges associated with nonbiodegradable membrane materials, it becomes imperative to consider alternate biodegradable polymeric membranes.

The use of biopolymers without synthetic polymers in membrane fabrication is a promising application due to their biodegradability, optical nature, and hydrophilicity. Some other biopolymers that have been blended with synthetic polymers include chitosan [91] and cyclodextrin [92]. Furthermore, because of the improved water permeability and rejection performances of the biodegradable biopolymers, it has become vital for researchers and inventors to further explore biopolymeric applications in membrane fabrication and water treatment. Most importantly, considerations should be made towards exclusively using biopolymers for water treatment instead of blending with synthetic polymers. This can be accomplished after addressing biopolymeric application challenges such as limited mechanical strength and their solubility capacity in various solvents suitable for membrane synthesis.

\section{Biopolymers' Applications}

Since biopolymers are predominantly hydrophilic, they are suitable for a variety of water treatment techniques such as adsorption and filtration applications. However, biopolymers tend to be more brittle and fragile, making them difficult to use under highly strenuous conditions. As such, their elasticity and tensile strength are compromised. In addition, most biopolymers are insoluble in most common solvents. Consequently, this limits their applications in various filtration applications [91,93]. Nevertheless, chemical modifications of biopolymers and blending biopolymers with synthetic polymers and nanomaterials tend to improve their flexibility and thermal stability [93]. Hence, Lu et al. [94] fabricated thermally stable silk nanofiber membranes by incorporating $\mathrm{CeO}_{2}$ nanoparticles. These modified membranes exhibited better tensile strength, flexibility, and elasticity properties.

Biopolymers have been considered in various forms in water treatment, as illustrated in Table 1. Biopolymers are predominantly utilized in packaging applications in South Africa [5,10,93]. Biopolymers have automotive, sports, adhesives, paints, and 
construction applications [5]. In addition, biopolymers have also been used in photographic films' and filtration membranes' synthesis and fabrication [10]. Biopolymers have also been applied in other industrial activities besides water treatment. For example, carrageenan has been used in different sectors such as drug delivery, packaging, and food additives $[28,95,96]$, whereas cellulose has been studied in drug delivery and textiles [97]. Starch has also been explored in food packaging [98,99]; fibrinogen in drug delivery and wound healing [100,101]; silk in wound healing [102,103]; collagen in tissue engineering [104-106] and drug delivery [107-109]; pullulan in drug delivery [110], food packaging, and food stabilizing [111,112]; alginate in biomedical applications [113,114]; chitin in tissue engineering [115] and enzyme immobilization [116,117]; and collagen in tissue engineering [104-106] and drug delivery [107-109]. However, our literature search demonstrated that biopolymers have limited applications in water treatment even though they possess useful properties such as hydrophilicity, an optical nature, and an easy-to-functionalize capacity. Therefore, Table 1 reports on the applications of biopolymers in water treatment.

Table 1. Reported applications of biopolymers in water treatment.

\begin{tabular}{|c|c|c|c|}
\hline Polymer & Nature of Material & Application & References \\
\hline Carrageenan & Aerogel & Water treatment-adsorption-desorption of heavy metals & [118] \\
\hline \multirow{3}{*}{ Cellulose } & Aerogel & $\begin{array}{c}\text { Water treatment-adsorption-desorption of heavy metals, } \\
\text { dyes, and oils }\end{array}$ & [119] \\
\hline & Film/membrane & Water treatment—various pollutants & {$[90,120,121]$} \\
\hline & Adsorbents & Adsorbent of $\mathrm{Zn}(\mathrm{II}), \mathrm{Co}(\mathrm{II}), \mathrm{Cd}(\mathrm{II})$, and $\mathrm{Ni}(\mathrm{II})$ & [122] \\
\hline Chitosan & Nanofibrous membrane & Water treatment-removal of heavy metals & [123] \\
\hline Cyclodextrins & Membranes & Water treatment: desalination & [92] \\
\hline Starch & Hydrogel & Nanoadsorbents for the removal of cationic dyes from water & [124] \\
\hline \multirow{2}{*}{ Silk } & $\begin{array}{c}\text { Aerogels } \\
\text { Fibrous membrane }\end{array}$ & Water treatment: removal of oil & [125-127] \\
\hline & Membranes & Water treatment: dye degradation & [128] \\
\hline Pullulan & Films, gels & Waste treatment: biosorption of heavy metals & {$[111,112]$} \\
\hline Alginate & Beads & Water treatment: adsorption of heavy metals & [129] \\
\hline Chitin & Nanofibrous membranes & $\begin{array}{c}\text { Water treatment: removal of organic hydrophobic } \\
\text { organic contaminant. }\end{array}$ & {$[130,131]$} \\
\hline
\end{tabular}

\section{Biopolymeric Membranes in Water Filtration}

Researchers have been developing new techniques as solutions for water treatment $[6,8,30,132]$. Green water treatment strategies that can enable water recycling are also being pursued [133]. Due to the incredible properties of biopolymers, it becomes ideal and attractive to utilize natural polymers towards membrane synthesis, fabrication, and production to prepare completely biodegradable membrane materials [86]. Pure biopolymers have been used on the fabrication of membranes for water treatment. These biopolymers/membranes can be utilized as adsorbents. For example, cellulose biopolymers and derivatives are being adapted for water filtration by fabricating them into ultrafiltration, nanofiltration, and osmotic membranes. Notably, these membranes are being used in the removal of contaminants such as dyes $[6,8,12,40]$, microorganisms $[8,134]$, heavy metals and salts $[6,8,135]$, pharmaceuticals $[8,38]$, pesticides, and oil/grease $[8,40]$. However, more work still needs to be done to improve the characteristics and performance properties of biopolymers [10].

Pandiarajan et al. [136] used orange peel-activated carbon for the removal of chlorophenoxyacetic acid herbicides from water via the adsorption-desorption technology. Consequently, this bio-sourced-activated carbon significantly adsorbed chlorophenoxyacetic acid herbicides from water. These biopolymers can be tuned into membranes. For example, cellulose polymers have been extensively utilized in water treatment membrane 
applications because of their plenteous polysaccharides. Hence, the polymers provide affordability and application in textile, paper [8], pharmaceutical, and membrane technology applications $[8,137]$. Different types of biopolymer-based membranes can be prepared such as blend membranes, nanofibrous membranes, mixed matrix membranes, imprinted membranes, and thin film composite membranes [8]. Janesh et al. [138] fabricated all biopolymer-based membranes based on chitin-glucan, chitosan-glucan, chitosan-glucan with cellulose for the removal of cationic pollutants through metal chelation. Additionally, Abdellah et al. [139] used cellulose blended with catechin membranes for the removal of DMF via solvent permeation. The membrane had a high DMF permeability of $1.2 \mathrm{Lm}^{-2} \mathrm{~h}^{-1} \mathrm{bar}^{-1}$ with a molecular weight cutoff of $500 \mathrm{~g} \mathrm{~mol}^{-1}$.

Primarily, the challenge with using biopolymers such as cellulose as a polymer for manufacturing membranes is that they are insoluble in common solvents. However, cellulose can be dissolved in N-methyl-morpholine-N-oxide (NMMO). In addition, cellulose can be dissolved in a dual-solvent system such as dimethylacetamide (DMAc)/lithium chloride ( $\mathrm{LiCl})[8,30,40,140]$, hydrazine/thiocyanate, $\mathrm{N}$-methylmorpholine-N-oxide (NMMO)/ water [140], and ammonium fluorides/dimethyl sulfoxide (DMSO). Fortunately, cellulose is compatible with other biopolymers, and this can help researchers create exclusive biobased mix materials. However, pristine biopolymers have limited adsorption capacity when compared to functionalized/modified biopolymers [8]. Thus, modifying biopolymers remains ideal for enhanced adsorption-desorption capacities, increased compatibility with other biopolymers, and solubilities in various solvents.

\subsection{Progress in the Preparation and Functionalisation of Biopolymers for Water Treatment}

In general, the disadvantage and limitation of biopolymers in water treatment applications is their mechanical instability $[19,141]$. The poor mechanical properties of biopolymers restrict their application in water filtration because of the high pressures that is used during water filtration. Hence, the biopolymeric membranes can break [141]. However, these properties can be enhanced through modification processes [10]. Consequently, the modifications cannot only improve the mechanical stability, but also the antifouling properties, self-cleaning capacities, and water permeability of the resultant membranes [1]. Thus, more work has been done to understand the effect of blending various types of synthesized or natural polymers with biopolymers to obtain maximum separation performance, such as higher flux, swelling capacity, permeation, and better selectivity [8].

Since biopolymers lack sufficient adsorptive-desorptive affinity towards organic pollutants such as cationic dyes, it is required that new functional groups are introduced, as illustrated in Scheme 1 using cellulose as an example. This includes the introduction of functional groups such as sulphur, amine, and hydroxyl, and carboxylic groups because of their higher affinity towards micropollutants. Notably, the ligands containing these functional groups can enhance the selectivity of modified membranes and significantly participate in the adsorption-desorption processes of contaminants [12]. The hydroxyl group on the cellulose backbone also coordinates with charged pollutants such as salts and heavy metals via electrostatic attraction, ion exchange, van der Waals forces, and hydrogen bonding [135].

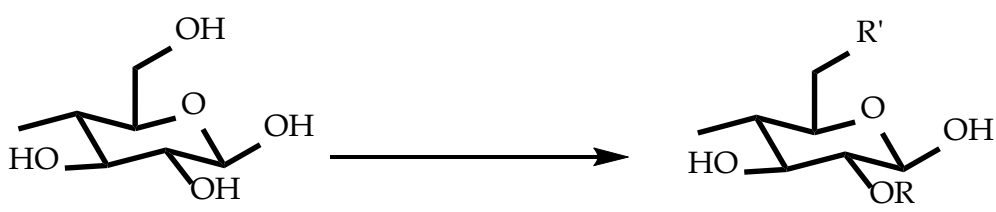

Cellulose

Modified Cellulose

Scheme 1. General scheme of cellulose modification where R and $R^{\prime}$ are functional moieties [142-146]. 
The introduction of the new functionalities to the backbone of the biopolymers such as cellulose has been achieved through various reactions. For example, cellulose modification is accomplished through the modification of the hydroxyl group along the cellulose chain $[6,10,144,147]$. Such modifications can be accomplished through cationization, phosphorylation [6,8], (2,2,6,6-tetramethyl-piperidin-1-yl)oxyl (TEMPO) oxidation [6,8,148], etherification, grafting, halogenation, carboxymethylation, sulfoethylation, sulfonation, aminoguanidine, ozonation, thiolation [6], esterification [6,10], acetylation [10], and amination $[6,143,144,149]$. The mechanisms of these reactions replace the proton of the hydroxy group of cellulose with functional groups, resulting in enhanced physico-chemical properties of the membrane [150].

Maleš et al. [12] modified cellulose with different functionalities into carboxymethyl cellulose (CMC), cellulose nanofibrils (CNF), and bacterial cellulose (BC) membranes. Consequently, these modified membranes efficiently removed azo and anthraquinone dyes from wastewater. The CMC and CNF membranes exhibited a 100\% removal efficiency against anthraquinone dye. However, all these modified biopolymeric membranes had low removal efficiencies against azo dyes. Biopolymers are useful in the removal of these pollutants because of their significant adsorption capacity. Most importantly, the biopolymers can be modified/blended into various derivatives to possess desired properties useful for water treatment, as discussed in Table 2.

Table 2. Several effective uses of biopolymeric membranes in water treatment.

\begin{tabular}{|c|c|c|c|c|}
\hline Membrane Types & Membrane Materials & $\begin{array}{l}\text { Pollutant Treated } \\
\text { with Membranes }\end{array}$ & Membrane Performance & References \\
\hline $\begin{array}{l}\text { Thin Film Composite } \\
\text { (TFC) by interfacial } \\
\text { polymerization }\end{array}$ & Catechin/cellulose & $\begin{array}{l}\text { Amido black dye (617 } \\
\qquad \mathrm{g} / \mathrm{mol})\end{array}$ & $92 \%$ rejection of dye was reported & [139] \\
\hline TFC membrane & Cellulose/polydopamine & $\mathrm{MgSO}_{2}$ & $\begin{array}{l}\text { Stable membranes with a rejection } \\
\text { capacity of up to } 75.6 \% \text { and water } \\
\text { flux of } 25.06 \mathrm{~L} \mathrm{~m}^{-2} \mathrm{~h}^{-1} \text { at a pressure } \\
\text { of } 0.4 \mathrm{MPa} \text { was reported. }\end{array}$ & [27] \\
\hline NF membranes & $\begin{array}{l}\text { Cellulose acetate blended } \\
\text { with Nicotiana tabacum } \\
\text { ash and Fe0 nanoparticles. } \\
\text { (ACA@Fe0) }\end{array}$ & $\begin{array}{c}\text { Congo Red (CR), } \\
\text { Methyl Blue (MB), } \\
\text { Methyl Orange }(\mathrm{MO}), \\
\text { 4-Nitrophenyl } \\
\text { phosphate (4NP) }\end{array}$ & $\begin{array}{l}\mathrm{CR}, \mathrm{MB}, \mathrm{MO} \text { dyes were reduced } \\
\text { using the ACA compared to } \\
\mathrm{ACA} @ \mathrm{Fe} 0 \text {; however, the } 4 \mathrm{NP} \text { was } \\
\text { reduced using the ACA@Fe0 }\end{array}$ & {$[14]$} \\
\hline NF membranes & $\begin{array}{l}\text { ZIF-8/chitosan/ } \\
\text { Polyvinyl alcohol }\end{array}$ & RG dye & $142.85 \mathrm{mg} \mathrm{g}^{-1}$ of dye was adsorbed & [151] \\
\hline NF membranes & $\begin{array}{l}\text { Bacterial cellulose } \\
\text { with MOFs }\end{array}$ & Nitrobenzene & $\begin{array}{l}\text { Water permeation of } \\
10.85 \mathrm{~L} \mathrm{~m}^{-2} \mathrm{~h}^{-1} \mathrm{psi}^{-1} \\
\text { rejection of nitrobenzene }(68.6 \%)\end{array}$ & [152] \\
\hline NF membranes & $\begin{array}{l}\text { Chitosan with oxidized } \\
\text { starch and silica }\end{array}$ & Blue 71 and Red 31 & $\begin{array}{l}\text { Good thermal stability and swelling } \\
\text { properties. Adsorption capacity } \\
\text { increased as the pH increased. }\end{array}$ & [153] \\
\hline $\begin{array}{l}\text { NF nanofibrous } \\
\text { membranes }\end{array}$ & $\begin{array}{c}\text { Hyper-crosslinked } \\
\text { cyclodextrin membranes }\end{array}$ & $\begin{array}{l}\mathrm{MB}, \text { Safranin } \mathrm{O} \text {, } \\
\text { rhodamine } \mathrm{B}, \mathrm{MO} \text {, } \\
\text { methyl red, } \mathrm{CR} \text {, rose } \\
\text { bengal, and direct } \\
\text { red } 80\end{array}$ & $\begin{array}{l}\text { adsorption capacity of } \\
\text { above } 180 \mathrm{mg} \mathrm{g}^{-1}\end{array}$ & [154] \\
\hline $\begin{array}{l}\text { NF nanofibrous } \\
\text { membrane }\end{array}$ & $\begin{array}{l}\text { Cross-linked } \\
\beta \text {-cyclodextrin }\end{array}$ & $\begin{array}{l}\text { steroid hormone: } \\
\text { estradiol }\end{array}$ & $\begin{array}{l}\text { removal efficiency of } 75 \% \text { after only } \\
180 \text { min and reaching the saturation } \\
\text { after } 5 \mathrm{~h} \text { with } 80 \% \text { removal }\end{array}$ & [155] \\
\hline TFC via coating & $\begin{array}{l}\text { Filter paper coated with } \\
\text { activated cellulose (cotton) }\end{array}$ & $\mathrm{MB}$ & $\begin{array}{c}98 \% \text { rejection at lower } \\
\text { concentrations (5-10 ppm), } 89 \% \\
\text { rejection at } 20 \mathrm{ppm} \\
78 \% \text { rejection at } 100 \mathrm{ppm}\end{array}$ & {$[40]$} \\
\hline
\end{tabular}


Table 2. Cont.

\begin{tabular}{|c|c|c|c|c|}
\hline Membrane Types & Membrane Materials & $\begin{array}{l}\text { Pollutant Treated } \\
\text { with Membranes }\end{array}$ & Membrane Performance & References \\
\hline $\begin{array}{l}\text { UF nanofibrous } \\
\text { membranes }\end{array}$ & La(OH) $)_{3} @$ cellulose & $\begin{array}{l}\text { Oils: } \\
\text { Hexane, cyclohexane, } \\
\text { toluene, pump oil, } \\
\text { crude oil, petroleum } \\
\text { ether; Dyes: CR, } \\
\text { MB, MO }\end{array}$ & $\begin{array}{l}\text { High water flux }\left(5897.7 \mathrm{~L} \mathrm{~m}^{-2} \mathrm{~h}^{-1}\right) \text {, } \\
\text { which is } 2 \text { times greater than } \\
\text { cellulose membranes. Above } 90 \% \\
\text { rejection of oils was observed. } \\
91.2 \% \text { of CR was adsorbed } \\
\text { effectively, whereas MB and MO } \\
\text { were not adsorbed. } \\
\text { Membrane was selective to CR. CR } \\
\text { was adsorbed from a } \\
\text { CR/MO mixture }\end{array}$ & {$[30]$} \\
\hline $\begin{array}{l}\text { UF nanofibrous } \\
\text { membrane }\end{array}$ & $\begin{array}{c}\text { Deacylated } \\
\text { cellulose/acetate with } \\
\text { polydopamine (DA@PDA) }\end{array}$ & MB & $\begin{array}{l}88.15 \mathrm{mg} / \mathrm{g} \text { was adsorbed, which is } \\
\text { about } 9 \text { times higher than the } \\
\text { adsorption observed on DA. }\end{array}$ & [34] \\
\hline $\begin{array}{l}\text { UF nanofibrous } \\
\text { membrane }\end{array}$ & $\begin{array}{l}\text { Cellulose nanofibril }(\mathrm{CNF}), \\
\text { Carboxymethylated } \\
\text { cellulose }(\mathrm{CMC}), \text { Bacterial } \\
\text { cellulose }(\mathrm{BC})\end{array}$ & $\begin{array}{l}\text { Anthraquinone dye } \\
\text { Azo dye }\end{array}$ & $\begin{array}{l}100 \% \text { rejection of anthraquinone dye } \\
\text { with CNF and CMC membranes and } \\
24.3 \% \text { rejection with } \mathrm{BC} \text {. } \\
\text { Less than } 10 \% \text { rejection was } \\
\text { observed on azo dye on } \\
\text { all membranes }\end{array}$ & [12] \\
\hline
\end{tabular}

\subsection{Removal of Organic Pollutants with Hybrid Biopolymeric Membranes}

Besides the modification of the biopolymers, nanomaterials can also be embedded into the biopolymer matrices to increase the performance and characteristic efficiencies of the biopolymeric membranes $[19,141]$. As such, several modification methods have been explored to functionalize biopolymeric membranes in pursuit of introducing functionalities and characteristics. For example, biopolymers were surface grafted, coated, and doped with nanoparticles [1]. In addition, the incorporation of nanofillers has also been adopted for biopolymeric membranes. The sizes and types of the nanofillers can influence the properties of the biopolymeric membranes. Notably, varying the nanofiller surface areato-volume ratio improves the properties of the membrane such as their catalytic activity, adhesion properties, electrical resistivity, and chemical reactivity $[24,141]$ and this has an impact on the effectiveness of the membrane, as illustrated on Figure 4.

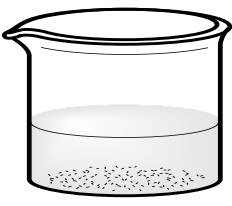

Casting solution

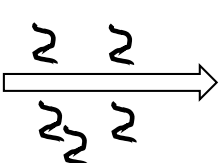

$\sum$ nanofiller

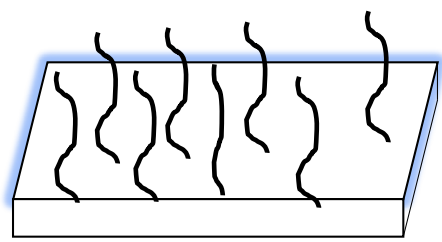

modified membrane
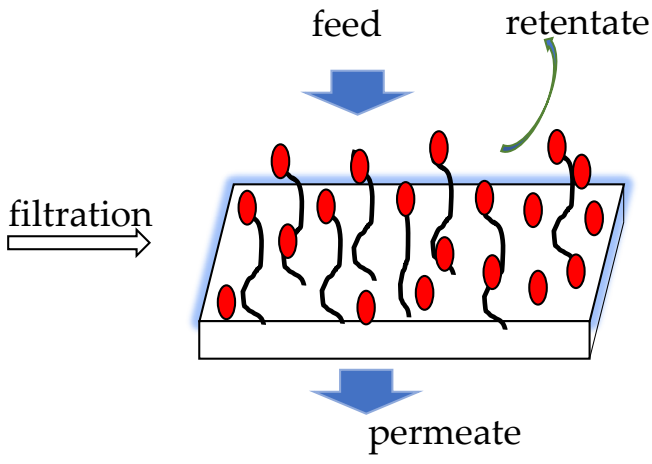

$0=$ pollutant

Figure 4. Illustration of polymer modification and filtration.

The nanoparticles increase the hydrophilicity of the biopolymeric membranes as well as their pollutants' removal efficiencies. As a result, this significantly increases the antifouling capabilities of the modified biopolymeric membranes [19,23]. Notably, nanomaterials 
have a large surface area. Consequently, this presents abundant active sites that remain exposed for interactions with pollutants. Furthermore, the reactivity and selectivity of nanostructured biopolymers towards the pollutants get increased as well as modified membrane's effectiveness [23]. The different sizes and shapes of nanofillers can determine the interaction capacity of the modified membranes with pollutants [24]. However, the size of the nanoparticles can be affected by various factors such as concentrations of reagents, mole ratio of reactants, reaction methods, and reaction time [156].

Nanofillers can be grouped into inorganic material, organic material [25,141], carbon nanostructures [141], and hybrid material [25]. For instance, the carbon nanostructures include carbon nanotubes and graphene sheets and inorganic nanofillers such as metal oxides and metals, among others [141]. Furthermore, organic nanofillers such as biopolymers such as cellulose, chitosan [141], and carrageenan have been used to modify synthetic polymeric membranes. Notably, metal oxides such as $\mathrm{TiO}_{2}$, tungsten oxide $\left(\mathrm{WO}_{3}\right)[1,21]$, $\mathrm{SnO}_{2}$ [1], $\mathrm{Ag}_{2} \mathrm{O}$ [156], $\mathrm{ZnO}[21,156]$ and silver phosphate $\left(\mathrm{Ag}_{2} \mathrm{PO}_{4}\right)$ [21] have been used to modify biopolymeric and synthetic membranes.

These nanoparticles are synthesized via various techniques. For example, Siddiqui et al. [156] synthesized silver oxide nanoparticles via the capping method while silver chloride nanoparticles were synthesized by simple precipitation of silver nitrate solution. Researchers synthesized $\mathrm{Ag}_{2} \mathrm{O}$ nanoparticles via the chemical precipitation reactions [157-159]. Other nanoparticles have been synthesized via the precipitation technique such as $\mathrm{ZnO}$ nanoparticles [160-162]. There are several nanofillers that have been explored in cellulose-based membrane production such as carbon nanotubes, nanoparticles, and nanosheets [8] as well as carbon-based nanomaterials such as the graphitic carbon nitrides.

Nanofillers can introduce new functionalities when incorporated into the biopolymeric membranes, improving their thermal and mechanical properties $[19,25,141]$, hydrophilicity, porosity $[19,25]$, antimicrobial and antioxidant properties $[8,24,25,141]$, photocatalytic properties [8,24,25], adsorption-desorption properties [8,24], and barrier properties [141]. The nanofiller impacts on biopolymeric membranes and synthetic performances are reported in Table 3.

Table 3. The effects of nanofillers on biopolymeric and synthetic membranes' behavior.

\begin{tabular}{|c|c|c|c|c|}
\hline Nanofillers & Material & Film Property & Effect on Membranes & References \\
\hline Sorbitol & Starch films & $\begin{array}{c}\text { Thermal properties, } \\
\text { morphology }\end{array}$ & $\begin{array}{l}\text { The sorbitol decreased the onset } \\
\text { temperature for the films, hence } \\
\text { improving the sealing process. } \\
\text { Uniform thickness at high } \\
\text { concentration of sorbitol. }\end{array}$ & [163] \\
\hline Sorbitol/glycerol & Alginate films & Mechanical properties & $\begin{array}{l}\text { The plasticizers increased the } \\
\text { plasticizing effect, hence increasing } \\
\text { the mechanical strength. }\end{array}$ & [164] \\
\hline $\begin{array}{l}\text { Multiwalled carbon } \\
\text { nanotube (MWCN) }\end{array}$ & Cellulose Membranes & Antifouling properties & $\begin{array}{l}\text { Improved antifouling characteristic } \\
\text { as the outer diameter of } \\
\text { MWCNT increases. }\end{array}$ & [165] \\
\hline \multirow{2}{*}{ Chitosan } & $\begin{array}{l}\text { Bacterial } \\
\text { cellulose/poly(vinyl } \\
\text { alcohol) membranes }\end{array}$ & Mechanical properties & $\begin{array}{l}\text { Improved mechanical properties; } \\
\text { reported tensile strength was } \\
130.55 \pm 9.42 \mathrm{MPa} \text {. }\end{array}$ & [166] \\
\hline & Polysulfone membranes & Antifouling properties & $\begin{array}{l}\text { Improved antifouling properties } \\
\text { with smoother surface after coating } \\
\text { with coating of CS-Ag nanomaterials }\end{array}$ & [16] \\
\hline $\begin{array}{l}\text { Bisphenol A-type- } \\
\text { benzoxazine } \\
\text { (BATB) }\end{array}$ & Amino cellulose (AC) & $\begin{array}{l}\text { Mechanical and } \\
\text { chemical properties }\end{array}$ & $\begin{array}{c}\text { Increased tensile strength } \\
\text { BATB was more thermally stable } \\
\text { than AC }\end{array}$ & [144] \\
\hline
\end{tabular}


Table 3. Cont.

\begin{tabular}{|c|c|c|c|c|}
\hline Nanofillers & Material & Film Property & Effect on Membranes & References \\
\hline $\begin{array}{c}\mathrm{ZnO}, \mathrm{CuO}, \mathrm{Ag}_{2} \mathrm{O} \\
\text { nanoparticles }\end{array}$ & Cellulose membranes & $\begin{array}{l}\text { Antimicrobial } \\
\text { properties }\end{array}$ & $\begin{array}{c}\text { Antimicrobial composite } \\
\text { membranes were achieved against } E \text {. } \\
\text { Coli, P. aeruginosa, B. subtilis, and } B \text {. } \\
\text { cereus strains. } \mathrm{Ag}_{2} \mathrm{O} / \text { cellulose had } \\
\text { the highest efficacy. }\end{array}$ & [157] \\
\hline Carrageenan & PVDF membranes & Hydrophilicity & $\begin{array}{l}\text { Increased permeability and water } \\
\text { flux due to increased porosity. } \\
71 \% \text { MO rejection compared to } 25 \% \\
\text { on pure PVDF }\end{array}$ & [13] \\
\hline $\mathrm{TiO}_{2}$ nanoparticles & PES membranes & $\begin{array}{l}\text { Hydrophilicity, } \\
\text { thermal, and } \\
\text { mechanical properties }\end{array}$ & $\begin{array}{c}\text { Increased hydrophilicity as } \mathrm{TiO}_{2} \\
\text { nanoparticle concentration } \\
\text { increased. } \\
\text { Maximum flux obtained at } 4-5 \mathrm{wt} \% \\
\text { of } \mathrm{TiO}_{2} \text { nanoparticles. } \\
\text { Thermally stable composites with } \\
\text { higher breaking strength and low } \\
\text { elongation ratio to PES } \\
\text { were produced }\end{array}$ & [83] \\
\hline
\end{tabular}

A study done by Xie et al. [167] demonstrated the effect of the nanofillers in starchbased membranes. Graphene oxide $/ \mathrm{Bi}_{2} \mathrm{WO}_{6}(\mathrm{GBW})$ was added onto starch membranes as a photocatalyst for ethylene degradation. The amount of $\mathrm{GO}$ on the starch membranes determined the effectiveness of the photocatalysis. When the addition of GO was $0.5 \%$, GBW/starch composite film showed the strongest visible light degradation activity for ethylene, and the rate constant $\mathrm{K}^{\prime}$ was $9.91 \times 10^{-4} \mathrm{~min}^{-1}$, 4.4 times that of pure $\mathrm{Bi}_{2} \mathrm{WO}_{6}$, whereas the $0.25 \%$ GO in GWB was less effective. The tensile strength of the membrane was greatly improved by the addition of GBW. As the amount of GO was increased, the tensile strength was also increased. A tensile strength of $23.19 \mathrm{MPa}$ was achieved when $1 \%$ of GO of GBW composite was used, as a result of the toughening effect on the polymer film and the hydrogen bonding between the polar groups on the surface of GBW and the hydroxyl groups in the starch molecules having a major role in improving the mechanical properties of the composite membrane [167].

Furthermore, Zhao et al. [132] prepared cellulose acetate/chitosan composite membranes that were enriched with activated carbon. Consequently, these modified membranes exhibited an enhanced water permeation flux of $9.09 \times 10^{3} \mathrm{~L} \mathrm{~m}^{-2} \mathrm{~h}^{-1}$, coupled with $99.6 \%$ rejection capacity of bisphenol A pollutants. This was accomplished at low pressures of $0.1 \mathrm{MPa}$. Such performances were attributed to the improved hydrophilicity and adsorption capability that was introduced by the activated carbon. Han et al. [165] incorporated multi-walled carbon nanotubes (MWCNTs) with various diameters $(10-20 \mathrm{~nm}, 20-40 \mathrm{~nm}$, and $40-60 \mathrm{~nm}$ ) into cellulose membranes. Their incorporation enhanced the antifouling and separation performances of the membranes. Notably, as the outer diameter of MWCNTs increased, the antifouling properties of the modified membranes also improved.

Abdelhameed et al. [168] reported the preparation of copper-benzene-1,3,5-tricarboxylate (BTC) metal-organic framework (Cu-BTC) on cotton (Cu-BTC@cotton) composite, which was intended for the removal of organophosphorus insecticides (ethion) from water. In their study, as the amount of copper on the composite membranes increased, the adsorption capacity also increased. For example, the pure cotton adsorption capacity was $10 \mathrm{mg} / \mathrm{g}$, $26.7 \mathrm{mg} / \mathrm{g}$ for the $5 \% \mathrm{Cu}$-BTC@Cotton, and $182 \mathrm{mg} / \mathrm{g}$ for 10\% Cu-BTC@Cotton. The removal percent of ethion exceeded $97 \%$ for the $10 \%$ composite after $120 \mathrm{~min}$. In a continuation to their study, Abdelhameed et al. [169] used CuBTC on cellulose acetate (Cu-BTC @CA) for the removal of another pesticide (dimethoate). The grafting of Cu-BTC onto CA membranes enhanced the adsorption from $207.8 \mathrm{mg} / \mathrm{g}$ to $282.3-321.9 \mathrm{mg} / \mathrm{g}$. Of note is that after five cycles of adsorption-desorption, the adsorption capacity of the composite membrane was 
decreased by $22.5 \%$. In another study, Garba et al. [170] were able to adsorb prometryn (Pr) herbicide using microcrystalline cellulose incorporated with copper, and obtained an adsorption capacity of $97.80 \mathrm{mg} / \mathrm{g}$ at ambient temperature, whereas at $50{ }^{\circ} \mathrm{C}$ the adsorption capacity increased to $119.70 \mathrm{mg} / \mathrm{g}$.

The solvent used for fabrication and the nanofiller type and fabrication techniques determines the resultant membrane morphology, as illustrated in Figure 5. Cellulose acetate membranes had larger pores when DMF was used as a casting solvent compared to when acetone was used. This can be attributed to the difference in evaporation rates [171].
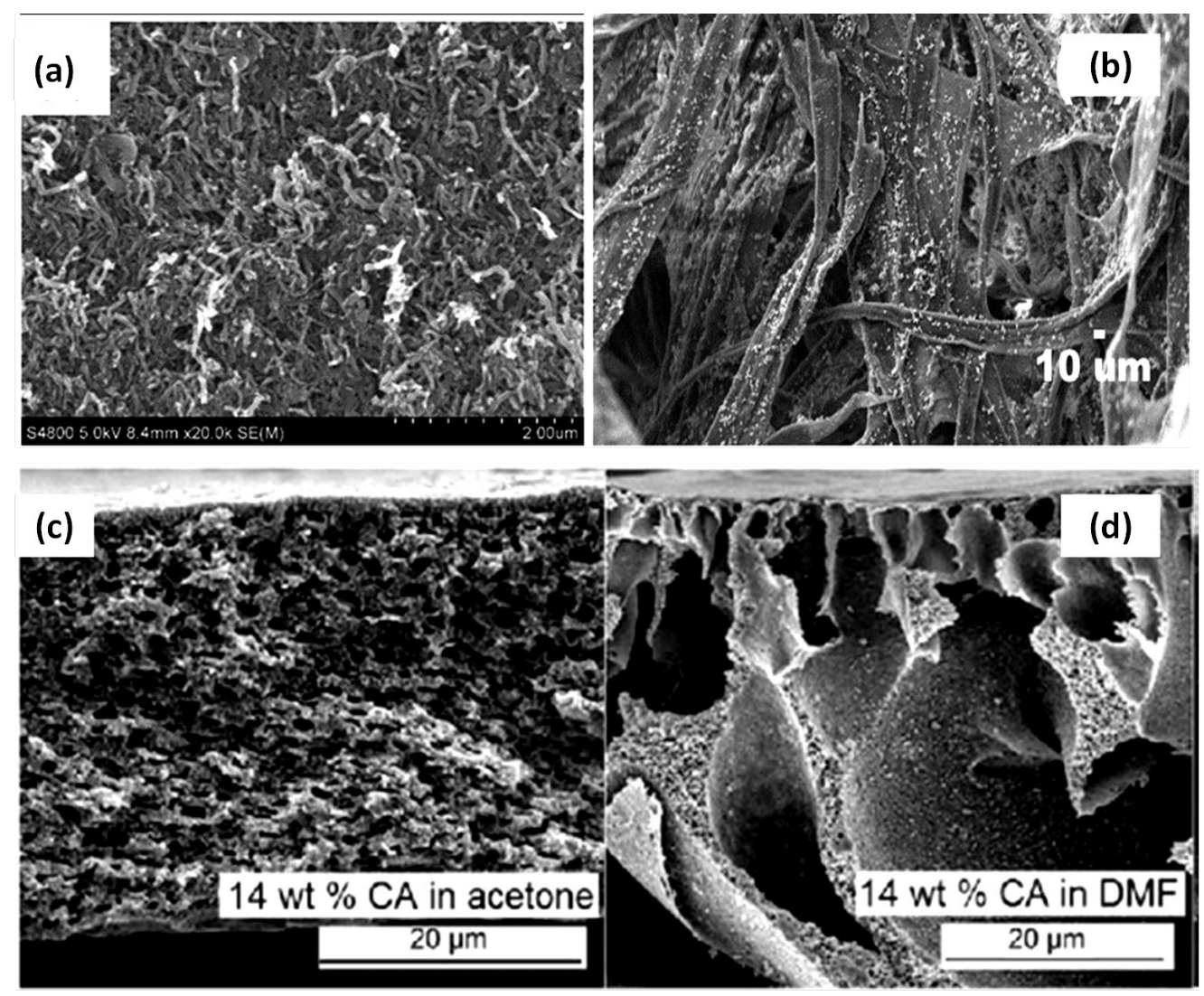

Figure 5. SEM micrographs of; (a) cellulose membranes incorporated with MWCNTs; (b) cellulose foam filter paper impregnated with $\mathrm{ZnO}$ nanoparticles; and (c) and (d) cross-sections of cellulose acetate membranes prepared from solutions in acetone and DMF, respectively. The micrographs were retrieved from literature: (a) [165], (b) [157], and (c) and (d) [171].

On the other hand, Ao et al. [30] immobilized $\mathrm{La}(\mathrm{OH})_{3}$ nanosheets onto cellulosebased membranes and this effectively improved the membranes' dye removal capabilities. For instance, the modified membrane's adsorption capacities were found to be $624 \mathrm{mg} / \mathrm{g}$ on Congo red (CR) compared to only $260 \mathrm{mg} / \mathrm{g}$ Congo red rejection of the unmodified cellulose-based membrane. This enhanced performance was attributable to ion exchange capacities on the modified membranes introduced by the $\mathrm{La}(\mathrm{OH})_{3}$ nanosheets. This was explained by the positively charged Congo red dye. The positive charge enabled the dye's easier attachment to the $\mathrm{O}$ - anion of the $\mathrm{OH}$ functional groups of both the cellulose and $\mathrm{La}(\mathrm{OH})_{3}$ nanosheets.

Cheng et al. [34] also tested the cellulose nanofibrous membranes incorporated with polydopamine on the adsorption of MB. These membranes exhibited an adsorption capacity of $88.15 \mathrm{mg} / \mathrm{g}$ at room temperature under $\mathrm{pH}$ of 6.5 , on an adsorption cycle of $30 \mathrm{~h}$. The increased adsorption capacity was attributed to the presence of amines brought by the polydopamine on which the cationic dyes tend to adsorb. These results reflect that cellulose-based membranes can be used for water filtration with optimum membrane performances for the treatment of organic pollutants in contaminated water depending on 
the polymer/membrane modifications. On another note, in an attempt to improve the hydrophilicity and rejection capacity of cellulose acetate, De Guzman et al. [172] incorporated polydopamine-sulfobetain nanoparticles, which improved the hydrophilicity of the membrane. These modified membranes had higher water flux (up to $583.64 \pm 25.12 \mathrm{~L} \mathrm{~m}^{-2} \mathrm{~h}^{-1}$ ) and a high rejection of oils (hexane, toluene, food oil, diesel, dodecane) [172].

Another way of modifying membranes to improve the physico-chemical properties is through crosslinking. For example, Zhao et al. [37] crosslinked P84 copolyimide membranes with polyethylenimine for the removal of two antibiotics (cefadroxil and enrofloxacin) using polyethylenimine cross-linked nanofiltration. Different molecular weight PEIs of 800, 2000, 25,000, and 750,000 $\mathrm{g} \cdot \mathrm{mol}^{-1}$ were utilized. Among these four membranes, the PEI-25k membrane had a high permeate flux compared to its counterparts. The crosslinking affected the membrane morphology. The P84 copolyimide membrane with no polyethylenimine had a thin and loose skin layer on top of a porous sublayer, whereas the P84 copolyimide modified with $25 \mathrm{k}$ polyethylenimine had a thicker and denser skin layer and was less porous. This is because during the crosslinking the PEI molecules diffused into the membrane, hence reducing the porosity of the membrane. The crosslinked membranes had $90 \%$ rejection of enrofloxacin molecules at $\mathrm{pH} 3-4$, which was due to the electrostatic repulsion between the positively charged enrofloxacin and membrane, whereas the enrofloxacin retention was low due to the electrostatic attraction between the positively charged membrane surface and negatively charged carboxyl groups of enrofloxacin [37].

Dodero et al. [173] investigated the use of phosphate ions (i.e., $\mathrm{Na}_{2} \mathrm{HPO}_{4}$ ) and ethylene glycol diglycidyl ether as crosslinkers on chitosan nanofibrous membrane. The success of the crosslinking was measured against morphological, mechanical, water-related, and biological properties. The use of phosphate ions crosslinked membranes were smooth, homogenous nanofibers with an average size of $190 \mathrm{~nm}$, whereas the ethylene glycol diglycidyl ether crosslinked membranes were rougher with average size of $270 \mathrm{~nm}$, which was bigger than their counterparts. The mechanical study revealed that the phosphate ions crosslinked membranes showed enhanced mechanical performances, as well as greater water vapor permeability and hydrophilicity, with respect to the chemically crosslinked ones. The tensile strength and Young modulus of the phosphate ions crosslinked membranes were almost twice those of the ethylene glycol diglycidyl ether crosslinked membranes [173].

Of note, the membrane specifications such as pore size and membrane thickness as well as the properties of nanoparticles incorporated are important in determining the effectiveness of the membrane. For example, Liu et al. [174] prepared sulfated cellulose nanocrystal membranes with an average pore size of $0.22 \mu \mathrm{m}$ and were able to reject tetracycline hydrochloride with a molecular weight of $480.90 \mathrm{~g} / \mathrm{mol}$. Additionally, $\mathrm{Li}$ et al. [175] rejected tetracycline with a molecular weight of $444.435 \mathrm{~g} / \mathrm{mol}$ and methyl orange via photocatalysis with a cellulose acetate membrane containing $\mathrm{H}_{4} \mathrm{SiW}_{12} \mathrm{O}_{40}$ and a pore size of $301.1 \mathrm{~nm}$. Tetracycline was also degraded by Shi et al. [176] using g- $\mathrm{C}_{3} \mathrm{~N}_{4} / \mathrm{BioBr}$ photocatalysts on carbon fibers.

\subsection{Challenges on the Implementation and Application of Biopolymers in Water Treatment}

The major hindrances for the development, upscaling, and reaching the market of biopolymeric membranes are their solubility and mechanical strength challenges. Biopolymers are insoluble in common solvents, which will make the production of the membranes pricey [91,93]. Additionally, biopolymeric membranes are mechanically weak compared to their nonbiodegradable counterparts, hence the need of blending, crosslinking, and introduction of nanofillers [177]. Even then, there is limited reporting on the upcycling and recycling of biopolymer membranes after use to determine the resilience in water treatment. Therefore, researchers still must address the solubility and mechanical strength challenges of biopolymers for maximal applications in adsorptive and membrane technology applications. 
Khaless et al. [178] demonstrated the possibility of recycling membranes in an attempt to apply them in the clarification of wet-process phosphoric acid. They demonstrated the possibility of recycling membranes in an attempt to use them in the clarification of wetprocess phosphoric acid. In this study, they proved the potential of recycling spent reverse osmosis (RO) membranes. The $\mathrm{RO}$ membranes were transformed into microfiltration (MF) membrane by stripping them with $\mathrm{NaOH}, \mathrm{KMnO}_{4}$, and $\mathrm{KMnO}_{4} / \mathrm{NaOH}$. The $\mathrm{MF}$ treated with $\mathrm{NAOH}$ were able to reject $61 \%$ of organic matter and $70 \%$ of suspended particles, which was better than the $\mathrm{KMnO}_{4}$-regenerated membranes, which had a $61 \%$ rejection of organic matter and $54 \%$ rejection of suspended particles. When it comes to membrane permeance and flux, it was reported that all the regenerated membranes showed an improvement from that of spent RO membranes. The previously spent membrane had a permeability of less than $1 \mathrm{~L} \mathrm{~m}^{-2} \mathrm{~h}^{-1} \mathrm{bar}^{-1}$, whereas the regenerated membranes using $\mathrm{NaOH}, \mathrm{KMnO}_{4}$, and $\mathrm{KMnO}_{4} / \mathrm{NaOH}$ had a permeability of $40 \mathrm{~L} \mathrm{~m}^{-2} \mathrm{~h}^{-1}, 45 \mathrm{~L} \mathrm{~m}^{-2} \mathrm{~h}^{-1}$, and $43 \mathrm{~L} \mathrm{~m}^{-2} \mathrm{~h}^{-1}$ bar $^{-1}$, respectively. The membrane permeability remained relatively the same after 7 days. Lastly, the wet-process phosphoric acid flux of the regenerated membranes was $43 \mathrm{~L} \mathrm{~m}^{-2} \mathrm{~h}^{-1}, 54 \mathrm{~L} \mathrm{~m}^{-2} \mathrm{~h}^{-1}$, and $53 \mathrm{~L} \mathrm{~m}^{-2} \mathrm{~h}^{-1}$ for $\mathrm{NaOH}-, \mathrm{KMnO}_{4-}$, and $\mathrm{KMnO}_{4} / \mathrm{NaOH}$-treated membranes. Likewise, the flux did not change significantly since it changed into $44 \mathrm{~L} \mathrm{~m}^{-2} \mathrm{~h}^{-1}, 56 \mathrm{~L} \mathrm{~m}^{-2} \mathrm{~h}^{-1}$, and $51 \mathrm{~L} \mathrm{~m}^{-2} \mathrm{~h}^{-1}$ after 7 days of use on the respective membranes.

In addition, Dai et al. [179] recycled used biopolymers for fabrication of highly permeating, thin-film composite membranes. Dai et al. used already-used biopolymers to fabricate high-permeance, thin-film composite polyamide membranes. In this study, fouled microfiltration membranes were upcycled for fabricating polyamide (PA) thin-film composite membranes via interfacial polymerization (IP) purposes. The thin film composite membranes had an average water permeability of $30 \mathrm{~L}^{-1} \mathrm{~m}^{-2} \mathrm{~h}^{-1} \mathrm{bar}^{-1}$ and $95 \%$ rejection of $\mathrm{Na}_{2} \mathrm{SO}_{4}$. Furthermore, some researchers [180,181] have demonstrated that biopolymers are biodegradable. For example, Fenyvesi et al. [181] demonstrated the degradation of cyclodextrin in soil and recorded more than 90\% degradation after 178 days. However, with all these promising decomposition performances, there is still limited appetite and efforts towards adopting biopolymers for various water treatment applications. Therefore, after use, the biopolymeric membranes can be used as compost under specific conditions such as temperature and moisture. Thus, more efforts should be towards comprehensively studying the decomposition rate of biopolymers to add value after use in compost creation.

\section{Conclusions}

Organic micropollutants are a threat to the environment across terrestrial and aquatic environments. Therefore, developing efficient, sustainable, and techno-economically membrane-based filtration systems can prevent short- and long-term toxic effects of the organic micropollutants. However, since synthetic polymeric membranes, which are currently being used to develop water treatment membranes, are non-biodegradable, considerations should be made towards biodegradable polymeric materials, to avoid secondary pollution. This means that biopolymers such as cellulose should be considered, especially because they are entirely biodegradable, abundant in nature, cost-effective, and affordable. Most importantly, natural biopolymers are unique because they are renewable, sustainable, nontoxic, and biocompatible. The blending technique has observed minimal applications because biopolymers are insoluble in common organic solvents and mechanically weak compared to nonbiodegradable membranes. As such, more research work should be carried out to address this limitation. In addition, the incorporated nanoparticles and functionalization of the biopolymers should be considered. Concerning biopolymeric membranes, to date, membrane antifouling properties, resistance to $\mathrm{pH}$, and stability under a variation of operating pressures and temperatures without any interference with the water flux and rejection capabilities have observed limited optimization. Thus, further investigations with this regard are required, to achieve practically sustainable direct biopolymeric membrane filtration operations. Thus, depending on the modification protocols of biopolymers such 
as increasing the aspect ratio, improving membrane's mechanical and enhancing their physico-chemical properties should be considered [182].

Author Contributions: Conceptualization, F.B.M., B.S.M. and J.R.; writing-first draft preparation, F.B.M.; Conceptualization, resources, writing-review and editing, supervision; B.S.M. and J.R.; visualization, F.B.M. All authors have read and agreed to the published version of the manuscript.

Funding: Funding has been received from DST/Mintek Nanotechnology Innovation Centre, University of Johannesburg, Johannesburg 2028, South Africa, The Centre for Nanomaterials Science Research, University of Johannesburg, Johannesburg 2028, South Africa, The University of Johannesburg, Faculty of Science, Department of Chemical Sciences, for the funding, and The National Research Foundation (NRF) Thuthuka.

Institutional Review Board Statement: Not applicable.

Informed Consent Statement: Not applicable.

Data Availability Statement: Data sharing not applicable.

Acknowledgments: The authors would like to thank the National Research Foundation (NRF) Thuthuka and the Centre for Nanomaterials Science Research, University of Johannesburg, for the funding. We would also like to acknowledge the University of Johannesburg, Faculty of Science, Department of Chemical Sciences for the opportunity to conduct this study and the DST/Mintek Nanotechnology Innovation Centre (NIC) for granting technical capacity that was necessary to conduct this research work.

Conflicts of Interest: The authors declare no conflict of interest.

\section{References}

1. Sun, S.; Yao, H.; Fu, W.; Xue, S.; Zhang, W. Enhanced Degradation of Antibiotics by Photo-Fenton Reactive Membrane Filtration. J. Hazard. Mater. 2020, 386, 1-11. [CrossRef] [PubMed]

2. Nam, S.-W.; Choi, D.-J.; Kim, S.-K.; Her, N.; Zoh, K.-D. Adsorption Characteristics of Selected Hydrophilic and Hydrophobic Micropollutants in Water Using Activated Carbon. J. Hazard. Mater. 2014, 270, 144-152. [CrossRef] [PubMed]

3. Boxall, A.B.A. New and Emerging Water Pollutants Arising from Agriculture; Organisation for Economic Co-Operation and Development: Paris, France, 2012.

4. Christian, S.J. Natural Fibre-Reinforced Noncementitious Composites (Biocomposites) of the chapter. In Nonconventional and Vernacular Construction Materials; Elsevier: Amsterdam, The Netherlands, 2020; pp. 169-187. [CrossRef]

5. Ibrahim, S.; Riahi, O.; Said, S.M.; Sabri, M.F.; Rozali, S. Biopolymers from Crop Plants. Ref. Modul. Mater. Sci. Mater. Eng. 2019, 1-10. [CrossRef]

6. Phan, D.-N.; Khan, M.Q.; Nguyen, N.-T.; Phan, T.-T.; Ullah, A.; Khatri, M.; Kien, N.N.; Kim, I.-S. A Review on the Fabrication of Several Carbohydrate Polymers into Nanofibrous Structures Using Electrospinning for Removal of Metal Ions and Dyes. Carbohydr. Polym. 2020, 252,1-15. [CrossRef]

7. Russo, T.; Fucile, P.; Giacometti, R.; Sannino, F. Sustainable Removal of Contaminants by Biopolymers: A Novel Approach for Wastewater Treatment. Current State and Future Perspectives. Processes 2021, 9, 719. [CrossRef]

8. Mansoori, S.; Davarnejad, R.; Matsuura, T.; Ismail, A.F. Membranes Based on Non-Synthetic (Natural) Polymers for Wastewater Treatment. Polym. Test. 2020, 84, 106381. [CrossRef]

9. Zain, M.; Fazelin, N.; Yusop, M.; Ahmad, I. Preparation and Characterization of Cellulose and Nanocellulose from Pomelo (Citrus Grandis) Albedo. Nutr. Food Sci. 2014, 5, 334. [CrossRef]

10. Rai, P.; Mehrotra, S.; Priya, S.; Gnansounou, E.; Sharma, S.K. Recent Advances in the Sustainable Design and Applications of Biodegradable Polymers. Bioresour. Technol. 2021, 325, 124739. [CrossRef]

11. Prasanna, N.S.; Mitra, J. Isolation and Characterization of Cellulose Nanocrystals from Cucumis Sativus Peels. Carbohydr. Polym. 2020, 247, 1-10. [CrossRef]

12. Maleš, L.; Fakin, D.; Bračič, M.; Gorgieva, S. Efficiency of Differently Processed Membranes Based on Cellulose as Cationic Dye Adsorbents. Nanomaterials 2020, 10, 642. [CrossRef]

13. Alam, J.; Alhoshan, M.; Shukla, A.K.; Aldalbahi, A.; Ali, F.A.A. K-Carrageenan-A Versatile Biopolymer for the Preparation of a Hydrophilic PVDF Composite Membrane. Eur. Polym. J. 2019, 120, 1-9. [CrossRef]

14. Aljohny, B.O.; Ahmad, Z.; Shah, S.A.; Anwar, Y.; Khan, S.A. Cellulose Acetate Composite Films Fabricated with Zero-Valent Iron Nanoparticles and Its Use in the Degradation of Persistent Organic Pollutants. Appl. Organomet. Chem. 2020, 34, 1-13. [CrossRef]

15. Yao, Q.; Fan, B.; Xiong, Y.; Jin, C.; Sun, Q.; Sheng, C. 3d Assembly Based on 2d Structure of Cellulose Nanofibril/Graphene Oxide Hybrid Aerogel for Adsorptive Removal of Antibiotics in Water. Sci. Rep. 2017, 7, 1-13. [CrossRef] 
16. Maalige, N.; Aruchamy, K.; Polishetti, V.; Halakarni, M.; Mahto, A.; Mondal, D.; Kotrappanavar, N.S. Restructuring Thin Film Composite Membrane Interfaces Using Biopolymer as a Sustainable Alternative to Prevent Organic Fouling. Carbohydr. Polym. 2021, 254, 1-12. [CrossRef]

17. Xu, L.; Zhou, Z.; Graham, N.J.; Liu, M.; Yu, W. Enhancing Ultrafiltration Performance by Gravity-Driven Up-Flow Slow Biofilter Pre-Treatment to Remove Natural Organic Matters and Biopolymer Foulants. Water Res. 2021, 195, 1-12. [CrossRef]

18. Asif, M.B.; Zhang, Z. Ceramic Membrane Technology for Water and Wastewater Treatment: A Critical Review of Performance, Full-Scale Applications, Membrane Fouling and Prospects. Chem. Eng. J. 2021, 418, 129481. [CrossRef]

19. Arsuaga, J.M.; Sotto, A.; Del Rosario, G.; Martínez, A.; Molina, S.; Teli, S.B.; De Abajo, J. Influence of the Type, Size, and Distribution of Metal Oxide Particles on the Properties of Nanocomposite Ultrafiltration Membranes. J. Membr. Sci. 2013, 428, 131-141. [CrossRef]

20. Deng, Y.-F.; Zhang, D.; Zhang, N.; Huang, T.; Lei, Y.-Z.; Wang, Y. Electrospun Stereocomplex Polylactide Porous Fibers toward Highly Efficient Oil/Water Separation. J. Hazard. Mater. 2020, 407, 1-11. [CrossRef]

21. Daub, N.A.; Aziz, F.; Aizat, A.; Yahya, N. Synthetic Polymer-Based Membranes for Photodegradation of Organic Hazardous Materials of the chapter. In Synthetic Polymeric Membranes for Advanced Water Treatment, Gas Separation, and Energy Sustainability; Elsevier: Amsterdam, The Netherlands, 2020; pp. 53-70. [CrossRef]

22. Arockiasamy, D.L.; Alhoshan, M.; Alam, J.; Muthumareeswaran, M.; Figoli, A.; Kumar, S.A. Separation of Proteins and Antifouling Properties of Polyphenylsulfone Based Mixed Matrix Hollow Fiber Membranes. Sep. Purif. Technol. 2017, 174, 529-543. [CrossRef]

23. Saleh, T.A.; Parthasarathy, P.; Irfan, M. Advanced Functional Polymer Nanocomposites and Their Use in Water Ultra-Purification. Trends Environ. Anal. Chem. 2019, 24, 1-11. [CrossRef]

24. Ahmad, K. Study of Different Polymer Nanocomposites and Their Pollutant Removal Efficiency. Polymer 2021, 217, 1-23. [CrossRef]

25. Esfahani, M.R.; Aktij, S.A.; Dabaghian, Z.; Firouzjaei, M.D.; Rahimpour, A.; Eke, J.; Escobar, I.C.; Abolhassani, M.; Greenlee, L.F.; Esfahani, A.R. Nanocomposite Membranes for Water Separation and Purification: Fabrication, Modification, and Applications. Sep. Purif. Technol. 2019, 213, 465-499. [CrossRef]

26. Tarchoun, A.F.; Trache, D.; Klapötke, T.M.; Krumm, B.; Kofen, M. Synthesis and Characterization of New Insensitive and High-Energy Dense Cellulosic Biopolymers. Fuel 2021, 292, 1-12. [CrossRef]

27. Wang, D.; Yuan, H.; Chen, Y.; Ni, Y.; Huang, L.; Mondal, A.K.; Lin, S.; Huang, F.; Zhang, H. A Cellulose-Based Nanofiltration Membrane with a Stable Three-Layer Structure for the Treatment of Drinking Water. Cellulose 2020, 27, 8237-8253. [CrossRef]

28. Agostinho, D.A.; Paninho, A.I.; Cordeiro, T.; Nunes, A.V.; Fonseca, I.M.; Pereira, C.; Matias, A.; Ventura, M.G. Properties of K-Carrageenan Aerogels Prepared by Using Different Dissolution Media and Its Application as Drug Delivery Systems. Mater. Chem. Phys. 2020, 253, 1-11. [CrossRef]

29. Gowthaman, N.; Lim, H.; Sreeraj, T.; Amalraj, A.; Gopi, S. Advantages of Biopolymers over Synthetic Polymers: Social, Economic, and Environmental Aspects of the chapter. In Biopolymers and Their Industrial Applications; Elsevier: Amsterdam, The Netherlands, 2021; pp. 351-372. [CrossRef]

30. Ao, C.; Zhao, J.; Xia, T.; Huang, B.; Wang, Q.; Gai, J.; Chen, Z.; Zhang, W.; Lu, C. Multifunctional La(OH) 3 @ Cellulose Nanofibrous Membranes for Efficient Oil/Water Separation and Selective Removal of Dyes. Sep. Purif. Technol. 2021, 254, 1-10. [CrossRef]

31. George, J.; Sabapathi, S. Cellulose Nanocrystals: Synthesis, Functional Properties, and Applications. Nanotechnol. Sci. Appl. 2015, 8, 45. [CrossRef]

32. Sudhakar, Y.; Selvakumar, M.; Bhat, D.K. Biopolymer Electrolytes: Fundamentals and Applications in Energy Storage; Elsevier: Amsterdam, The Netherlands, 2018; pp. 1-34. [CrossRef]

33. Song, W.; Lee, L.Y.; Ng, H.Y. Nanofiltration and Reverse Osmosis Processes for the Removal of Micro-Pollutants of the chapter. In Current Developments in Biotechnology and Bioengineering; Elsevier: Amsterdam, The Netherlands, 2020; pp. 527-552.

34. Cheng, J.; Zhan, C.; Wu, J.; Cui, Z.; Si, J.; Wang, Q.; Peng, X.; Turng, L.-S. Highly Efficient Removal of Methylene Blue Dye from an Aqueous Solution Using Cellulose Acetate Nanofibrous Membranes Modified by Polydopamine. ACS Omega 2020, 5, 5389-5400. [CrossRef]

35. Tröger, R.; Klöckner, P.; Ahrens, L.; Wiberg, K. Micropollutants in Drinking Water from Source to Tap-Method Development and Application of a Multiresidue Screening Method. Sci. Total Environ. 2018, 627, 1404-1432. [CrossRef]

36. Crini, G.; Lichtfouse, E. Advantages and Disadvantages of Techniques Used for Wastewater Treatment. Environ. Chem. Lett. 2019, 17, 145-155. [CrossRef]

37. Zhao, S.; Ba, C.; Yao, Y.; Zheng, W.; Economy, J.; Wang, P. Removal of Antibiotics Using Polyethylenimine Cross-Linked Nanofiltration Membranes: Relating Membrane Performance to Surface Charge Characteristics. Chem. Eng. J. 2018, 335, 101-109. [CrossRef]

38. Pandele, A.M.; Iovu, H.; Orbeci, C.; Tuncel, C.; Miculescu, F.; Nicolescu, A.; Deleanu, C.; Voicu, S.I. Surface Modified Cellulose Acetate Membranes for the Reactive Retention of Tetracycline. Sep. Purif. Technol. 2020, 249, 1-9. [CrossRef]

39. Warsinger, D.M.; Chakraborty, S.; Tow, E.W.; Plumlee, M.H.; Bellona, C.; Loutatidou, S.; Karimi, L.; Mikelonis, A.M.; Achilli, A.; Ghassemi, A. A Review of Polymeric Membranes and Processes for Potable Water Reuse. Prog. Polym. Sci. 2018, 81, 209-237. [CrossRef]

40. Ao, C.; Zhao, J.; Li, Q.; Zhang, J.; Huang, B.; Wang, Q.; Gai, J.; Chen, Z.; Zhang, W.; Lu, C. Biodegradable All-Cellulose Composite Membranes for Simultaneous Oil/Water Separation and Dye Removal from Water. Carbohydr. Polym. 2020, 250, 1-11. [CrossRef] 
41. Virkutyte, J.; Varma, R. Treatment of Micropollutants in Water and Wastewater; IWA Publishing: London, UK, 2010 ; pp. 1-503.

42. Kim, M.-K.; Zoh, K.-D. Occurrence and Removals of Micropollutants in Water Environment. Environ. Eng. Res. 2016, 21, 319-332. [CrossRef]

43. Tornero, V.; Hanke, G. Chemical Contaminants Entering the Marine Environment from Sea-Based Sources: A Review with a Focus on European Seas. Mar. Pollut. Bull. 2016, 112, 17-38. [CrossRef]

44. Rogowska, J.; Cieszynska-Semenowicz, M.; Ratajczyk, W.; Wolska, L. Micropollutants in Treated Wastewater. Ambio 2020, 49, 487-503. [CrossRef] [PubMed]

45. K'oreje, K.O.; Okoth, M.; Van Langenhove, H.; Demeestere, K. Occurrence and Treatment of Contaminants of Emerging Concern in the African Aquatic Environment: Literature Review and a Look Ahead. J. Environ. Manag. 2020, 254, 1-18. [CrossRef] [PubMed]

46. Koyuncu, I.; Arikan, O.A.; Wiesner, M.R.; Rice, C. Removal of Hormones and Antibiotics by Nanofiltration Membranes. J. Membr. Sci. 2008, 309, 94-101. [CrossRef]

47. Brody, J.G.; Moysich, K.B.; Humblet, O.; Attfield, K.R.; Beehler, G.P.; Rudel, R.A. Environmental Pollutants and Breast Cancer: Epidemiologic Studies. Cancer Interdiscip. Int. J. Am. Cancer Soc. 2007, 109, 2667-2711. [CrossRef]

48. Raza, W.; Lee, J.; Raza, N.; Luo, Y.; Kim, K.-H.; Yang, J. Removal of Phenolic Compounds from Industrial Waste Water Based on Membrane-Based Technologies. J. Indust. Eng. Chem. 2019, 71, 1-18. [CrossRef]

49. Altintas, Z.; Chianella, I.; Da Ponte, G.; Paulussen, S.; Gaeta, S.; Tothill, I.E. Development of Functionalized Nanostructured Polymeric Membranes for Water Purification. Chem. Eng. J. 2016, 300, 358-366. [CrossRef]

50. Chavoshani, A.; Hashemi, M.; Amin, M.M.; Ameta, S.C. Pharmaceuticals as Emerging Micropollutants in Aquatic Environments of the chapter. In Micropollutants and Challenges-Emerging in the Aquatic Environments and Treatment Processes; Elsevier: Amsterdam, The Netherlands, 2020; pp. 35-90. [CrossRef]

51. Vasilachi, I.C.; Asiminicesei, D.M.; Fertu, D.I.; Gavrilescu, M. Occurrence and Fate of Emerging Pollutants in Water Environment and Options for Their Removal. Water 2021, 13, 181. [CrossRef]

52. Radeva, J.; Roth, A.G.; Göbbert, C.; Niestroj-Pahl, R.; Dähne, L.; Wolfram, A.; Wiese, J. Hybrid Ceramic Membranes for the Removal of Pharmaceuticals from Aqueous Solutions. Membranes 2021, 11, 280. [CrossRef] [PubMed]

53. Stylianou, S.K.; Szymanska, K.; Katsoyiannis, I.A.; Zouboulis, A.I. Novel Water Treatment Processes Based on Hybrid MembraneOzonation Systems: A Novel Ceramic Membrane Contactor for Bubbleless Ozonation of Emerging Micropollutants. J. Chem. 2015, 2015, 1-12. [CrossRef]

54. Tsapovsky, L.; Simhon, M.; Calderone, V.R.; Rothenberg, G.; Gitis, V. Retention of Organics and Degradation of Micropollutants in Municipal Wastewater Using Impregnated Ceramics. Clean Technol. Environ. Policy 2020, 22, 689-700. [CrossRef]

55. Kanaujiya, D.K.; Paul, T.; Sinharoy, A.; Pakshirajan, K. Biological Treatment Processes for the Removal of Organic Micropollutants from Wastewater: A Review. Curr. Pollut. Rep. 2019, 5, 112-128. [CrossRef]

56. Kümmerer, K.; Dionysiou, D.D.; Olsson, O.; Fatta-Kassinos, D. Reducing Aquatic Micropollutants-Increasing the Focus on Input Prevention and Integrated Emission Management. Sci. Total Environ. 2019, 652, 836-850. [CrossRef] [PubMed]

57. Sparks, C.; Awe, A.; Maneveld, J. Abundance and Characteristics of Microplastics in Retail Mussels from Cape Town, South Africa. Mar. Pollut. Bull. 2021, 166, 1-7. [CrossRef]

58. Beaumont, N.J.; Aanesen, M.; Austen, M.C.; Börger, T.; Clark, J.R.; Cole, M.; Hooper, T.; Lindeque, P.K.; Pascoe, C.; Wyles, K.J. Global Ecological, Social and Economic Impacts of Marine Plastic. Mar. Pollut. Bull. 2019, 142, 189-195. [CrossRef]

59. Collins, C.; Hermes, J. Modelling the Accumulation and Transport of Floating Marine Micro-Plastics around South Africa. Mar. Pollut. Bull. 2019, 139, 46-58. [CrossRef] [PubMed]

60. WHO. C 9: Radiological Aspects. In Guidelines for Drinking-Water Quality. 4th Ed. Incorporating the 1st Addendum; World Health Organization: Geneva, Switzerland, 2017; pp. 203-218.

61. Linking Agenda 2063 and the Sdgs. Available online: https://au.int/en/agenda2063/sdgs (accessed on 31 July 2021).

62. South Africa's Implementation of the 2030 Agenda for Sustainable Development; South African Government: Pretoria, South Africa, 2019.

63. Nkosi, B.R.; Odeku, K.O. Analysis of Water Pollution Control Laws in South Africa. Mediterr. J. Soc. Sci. 2014, 5, $2572-2582$. [CrossRef]

64. Department of Environmental Affairs Strives to Improve Plastic Bag Recycling in South Africa. 2017. Available online: https: //www.environment.gov.za/mediarelease/deaonimproveplasticbagrecyclinginSA (accessed on 8 October 2021).

65. Vallabh, D.; Molebale, L.; Futshane, A. Pastics and Packaging Laws in South Africa. Available online: https://cms.law/en/int/ expert-guides/plastics-and-packaging-laws/south-africa (accessed on 8 October 2021).

66. Mansas, C.; Mendret, J.; Brosillon, S.; Ayral, A. Coupling Catalytic Ozonation and Membrane Separation: A Review. Sep. Purif. Technol. 2020, 236, 1-29. [CrossRef]

67. Li, C.; Sun, W.; Lu, Z.; Ao, X.; Yang, C.; Li, S. Systematic Evaluation of $\mathrm{TiO}_{2}-\mathrm{GO}-$ Modified Ceramic Membranes for Water Treatment: Retention Properties and Fouling Mechanisms. Chem. Eng. J. 2019, 378, 1-12. [CrossRef]

68. Lee, W.J.; Bao, Y.; Hu, X.; Lim, T.-T. Hybrid Catalytic Ozonation-Membrane Filtration Process with CeO $\mathrm{x}_{\mathrm{x}}$ and $\mathrm{Mnox}_{\mathrm{Impregnated}}$ Catalytic Ceramic Membranes for Micropollutants Degradation. Chem. Eng. J. 2019, 378, 1-12. [CrossRef]

69. Alshahrani, A.; Alharbi, A.; Alnasser, S.; Almihdar, M.; Alsuhybani, M.; Alotaibi, B. Enhanced Heavy Metals Removal by a Novel Carbon Nanotubes Buckypaper Membrane Containing a Mixture of Two Biopolymers: Chitosan and I-Carrageenan. Sep. Purif. Technol. 2021, 276, 1-9. [CrossRef] 
70. Pulido, B.; Waldron, C.; Zolotukhin, M.; Nunes, S.P. Porous Polymeric Membranes with Thermal and Solvent Resistance. J. Membr. Sci. 2017, 539, 187-196. [CrossRef]

71. Ba, C.; Langer, J.; Economy, J. Chemical Modification of P84 Copolyimide Membranes by Polyethylenimine for Nanofiltration. J. Membr. Sci. 2009, 327, 49-58. [CrossRef]

72. Lee, H.; Im, S.-J.; Lee, H.; Kim, C.-M.; Jang, A. Comparative Analysis of Salt Cleaning and Osmotic Backwash on Calcium-Bridged Organic Fouling in Nanofiltration Process. Desalination 2021, 507, 115022. [CrossRef]

73. Kumar, R.; Ismail, A. Fouling Control on Microfiltration/Ultrafiltration Membranes: Effects of Morphology, Hydrophilicity, and Charge. J. Appl. Polym. Sci. 2015, 132, 1-20. [CrossRef]

74. Katsoufidou, K.; Yiantsios, S.; Karabelas, A. Experimental Study of Ultrafiltration Membrane Fouling by Sodium Alginate and Flux Recovery by Backwashing. J. Membr. Sci. 2007, 300, 137-146. [CrossRef]

75. Leaper, S.; AvendañO CáCeres, E.O.; Luque-Alled, J.M.; Cartmell, S.H.; Gorgojo, P. Poss-Functionalized Graphene Oxide/PVDF Electrospun Membranes for Complete Arsenic Removal Using Membrane Distillation. ACS Appl. Polym. Mater. 2021, 3, $1854-1865$. [CrossRef]

76. Nawaz, H.; Umar, M.; Ullah, A.; Razzaq, H.; Zia, K.M.; Liu, X. Polyvinylidene Fluoride Nanocomposite Super Hydrophilic Membrane Integrated with Polyaniline-Graphene Oxide Nano Fillers for Treatment of Textile Effluents. J. Hazard. Mater. 2021, 403, 1-13. [CrossRef]

77. Vatanpour, V.; Khadem, S.S.M.; Dehqan, A.; Al-Naqshabandi, M.A.; Ganjali, M.R.; Hassani, S.S.; Rashid, M.R.; Saeb, M.R.; Dizge, N. Efficient Removal of Dyes and Proteins by Nitrogen-Doped Porous Graphene Blended Polyethersulfone Nanocomposite Membranes. Chemosphere 2021, 263, 1-10. [CrossRef] [PubMed]

78. Abdulkarem, E.; Ibrahim, Y.; Kumar, M.; Arafat, H.A.; Naddeo, V.; Banat, F.; Hasan, S.W. Polyvinylidene Fluoride (PVDF)-AZirconium Phosphate (A-Zrp) Nanoparticles Based Mixed Matrix Membranes for Removal of Heavy Metal Ions. Chemosphere 2021, 267, 1-10. [CrossRef] [PubMed]

79. Dehghankar, M.; Mohammadi, T.; Moghadam, M.T.; Tofighy, M.A. Metal-Organic Framework/Zeolite Nanocrystal/Polyvinylidene Fluoride Composite Ultrafiltration Membranes with Flux/Antifouling Advantages. Mater. Chem. Phys. 2021, 260, 1-15. [CrossRef]

80. Mamah, S.C.; Goh, P.S.; Ismail, A.F.; Suzaimi, N.D.; Ahmad, N.A.; Lee, W.J. Flux Enhancement in Reverse Osmosis Membranes Induced by Synergistic Effect of Incorporated Palygorskite/Chitin Hybrid Nanomaterial. J. Environ. Chem. Eng. 2021, 9, 1-12. [CrossRef]

81. Mutharasi, Y.; Zhang, Y.; Weber, M.; Maletzko, C.; Chung, T.-S. Novel Reverse Osmosis Membranes Incorporated with Co-Al Layered Double Hydroxide (Ldh) with Enhanced Performance for Brackish Water Desalination. Desalination 2021, 498, 1-10. [CrossRef]

82. Balta, S.; Sotto, A.; Luis, P.; Benea, L.; Van Der Bruggen, B.; Kim, J. A New Outlook on Membrane Enhancement with Nanoparticles: The Alternative of Zno. J. Membr. Sci. 2012, 389, 155-161. [CrossRef]

83. Li, J.-F.; Xu, Z.-L.; Yang, H.; Yu, L.-Y.; Liu, M. Effect of $\mathrm{TiO}_{2}$ Nanoparticles on the Surface Morphology and Performance of Microporous PES Membrane. App. Surf. Sci. 2009, 255, 4725-4732. [CrossRef]

84. Cao, X.; Ma, J.; Shi, X.; Ren, Z. Effect of $\mathrm{TiO}_{2}$ Nanoparticle Size on the Performance of PVDF Membrane. App. Surf. Sci. 2006, 253, 2003-2010. [CrossRef]

85. Beck, S.; Narain, R. Polymer Synthesis. In Polymer Science and Nanotechnology: Fundamentals and Applications; Elsevier: Amsterdam, The Netherlands, 2020; pp. 21-85. [CrossRef]

86. Moore, C.J. Synthetic Polymers in the Marine Environment: A Rapidly Increasing, Long-Term Threat. Environ. Res. 2008, 108, 131-139. [CrossRef]

87. Rios, L.M.; Moore, C.; Jones, P.R. Persistent Organic Pollutants Carried by Synthetic Polymers in the Ocean Environment. Mar. Pollut. Bull. 2007, 54, 1230-1237. [CrossRef] [PubMed]

88. Santana-Viera, S.; Montesdeoca-Esponda, S.; Guedes-Alonso, R.; Sosa-Ferrera, Z.; Santana-Rodríguez, J.J. Organic Pollutants Adsorbed on Microplastics: Analytical Methodologies and Occurrence in Oceans. Trends Environ. Anal. Chem. 2021, 29 , e00114. [CrossRef]

89. Berber, M.R. Current Advances of Polymer Composites for Water Treatment and Desalination. J. Chem. 2020, 2020, 1-19. [CrossRef]

90. Kumar, M.; Raot, S.; Isloor, A.M.; Ibrahim, G.S.; Ismail, N.; Ismail, A.F.; Asiri, A.M. Use of Cellulose Acetate/Polyphenylsulfone Derivatives to Fabricate Ultrafiltration Hollow Fiber Membranes for the Removal of Arsenic from Drinking Water. Int. J. Biol. Macro. 2019, 129, 715-727. [CrossRef] [PubMed]

91. Rathi, B.S.; Kumar, P.S.; Vo, D.-V.N. Critical Review on Hazardous Pollutants in Water Environment: Occurrence, Monitoring, Fate, Removal Technologies and Risk Assessment. Sci. Total Environ. 2021, 797, 1-22. [CrossRef]

92. Mbuli, B.S.; Nxumalo, E.N.; Krause, R.W.; Pillay, V.L.; Oren, Y.; Linder, C.; Mamba, B.B. Modification of Polyamide Thin-Film Composite Membranes with Amino-Cyclodextrins and Diethylamino-Cyclodextrins for Water Desalination. Sep. Purif. Technol. 2013, 120, 328-340. [CrossRef]

93. Mehariya, S.; Marino, T.; Casella, P.; Iovine, A.; Leone, G.P.; Musmarra, D.; Molino, A. Biorefinery for Agro-Industrial Waste into Value-Added Biopolymers: Production and Applications of the chapter. In Biorefineries: A Step Towards Renewable and Clean Energy; Springer: Berlin/Heidelberg, Germany, 2020; pp. 1-19. [CrossRef] 
94. Lu, Z.; Mao, C.; Meng, M.; Liu, S.; Tian, Y.; Yu, L.; Sun, B.; Li, C.M. Fabrication of $\mathrm{CeO}_{2}$ Nanoparticle-Modified Silk for Uv Protection and Antibacterial Applications. J. Colloid Interface Sci. 2014, 435, 8-14. [CrossRef]

95. Farhan, A.; Hani, N.M. Characterization of Edible Packaging Films Based on Semi-Refined Kappa-Carrageenan Plasticized with Glycerol and Sorbitol. Food Hydrocoll. 2017, 64, 48-58. [CrossRef]

96. Berton, S.B.; De Jesus, G.A.; Sabino, R.M.; Monteiro, J.P.; Venter, S.A.; Bruschi, M.L.; Popat, K.C.; Matsushita, M.; Martins, A.F.; Bonafé, E.G. Properties of a Commercial K-Carrageenan Food Ingredient and Its Durable Superabsorbent Hydrogels. Carbohydr. Res. 2020, 487, 1-9. [CrossRef] [PubMed]

97. Valo, H.; Arola, S.; Laaksonen, P.; Torkkeli, M.; Peltonen, L.; Linder, M.B.; Serimaa, R.; Kuga, S.; Hirvonen, J.; Laaksonen, T. Drug Release from Nanoparticles Embedded in Four Different Nanofibrillar Cellulose Aerogels. Eur. J. Pharm. Sci. 2013, 50, 69-77. [CrossRef] [PubMed]

98. Da Costa, J.C.M.; Miki, K.S.L.; Da Silva Ramos, A.; Teixeira-Costa, B.E. Development of Biodegradable Films Based on Purple Yam Starch/Chitosan for Food Application. Heliyon 2020, 6, 1-10. [CrossRef]

99. Solano, A.C.V.; De Gante, C.R. Development of Biodegradable Films Based on Blue Corn Flour with Potential Applications in Food Packaging. Effects of Plasticizers on Mechanical, Thermal, and Microstructural Properties of Flour Films. J. Cereal Sci. 2014, 60, 60-66. [CrossRef]

100. Zadeh, F.J.; Mohammadtaghizadeh, M.; Bahadori, H.; Saki, N.; Rezaeeyan, H. The Role of Exogenous Fibrinogen in Cardiac Surgery: Stop Bleeding or Induce Cardiovascular Disease. Mol. Biol. Rep. 2020, 47, 8189-8198. [CrossRef]

101. Jakate, A.S.; Einhaus, C.M.; Deanglis, A.P.; Retzinger, G.S.; Desai, P.B. Preparation, Characterization, and Preliminary Application of Fibrinogen-Coated Olive Oil Droplets for the Targeted Delivery of Docetaxel to Solid Malignancies. Cancer Res. 2003, 63, 7314-7320. [PubMed]

102. Pollini, M.; Paladini, F. Bioinspired Materials for Wound Healing Application: The Potential of Silk Fibroin. Materials 2020, 13, 3361. [CrossRef] [PubMed]

103. Li, Z.; Song, J.; Zhang, J.; Hao, K.; Liu, L.; Wu, B.; Zheng, X.; Xiao, B.; Tong, X.; Dai, F. Topical Application of Silk Fibroin-Based Hydrogel in Preventing Hypertrophic Scars. Colloids Surf. B 2020, 186, 110735. [CrossRef] [PubMed]

104. Buttafoco, L.; Kolkman, N.G.; Engbers-Buijtenhuijs, P.; Poot, A.A.; Dijkstra, P.J.; Vermes, I.; Feijen, J. Electrospinning of Collagen and Elastin for Tissue Engineering Applications. Biomaterials 2006, 27, 724-734. [CrossRef]

105. Kim, C.-L.; Kim, D.-E. Self-Healing Characteristics of Collagen Coatings with Respect to Surface Abrasion. Sci. Rep. 2016, 6, 1-11. [CrossRef] [PubMed]

106. Tytgat, L.; Dobos, A.; Markovic, M.; Van Damme, L.; Van Hoorick, J.; Bray, F.; Thienpont, H.; Ottevaere, H.; Dubruel, P.; Ovsianikov, A. High-Resolution 3d Bioprinting of Photo-Cross-Linkable Recombinant Collagen to Serve Tissue Engineering Applications. Biomacromolecules 2020, 21, 3997-4007. [CrossRef]

107. Xeroudaki, M.; Thangavelu, M.; Lennikov, A.; Ratnayake, A.; Bisevac, J.; Petrovski, G.; Fagerholm, P.; Rafat, M.; Lagali, N. A Porous Collagen-Based Hydrogel and Implantation Method for Corneal Stromal Regeneration and Sustained Local Drug Delivery. Sci. Rep. 2020, 10, 1-18. [CrossRef]

108. Lee, D.; Wufuer, M.; Kim, I.; Choi, T.H.; Kim, B.J.; Jung, H.G.; Jeon, B.; Lee, G.; Jeon, O.H.; Chang, H. Sequential Dual-Drug Delivery of Bmp-2 and Alendronate from Hydroxyapatite-Collagen Scaffolds for Enhanced Bone Regeneration. Sci. Rep. 2021, 11, 1-10. [CrossRef]

109. Nguyen, C.T.; Vu, M.Q.; Phan, T.T.; Vu, T.Q.; Vo, Q.A.; Bach, G.L.; Thai, H. Novel pH-Sensitive Hydrogel Beads Based on Carrageenan and Fish Scale Collagen for Allopurinol Drug Delivery. J. Polym. Environ. 2020, 28, 1795-1810. [CrossRef]

110. Ganie, S.A.; Rather, L.J.; Li, Q. A Review on Anticancer Applications of Pullulan and Pullulan Derivative Nanoparticles. Carbohydr. Polym. Technol. Appl. 2021, 2, 1-17. [CrossRef]

111. Luís, Â.; Ramos, A.; Domingues, F. Pullulan Films Containing Rockrose Essential Oil for Potential Food Packaging Applications. Antibiotics 2020, 9, 681. [CrossRef] [PubMed]

112. Pandey, A.K.; Sirohi, R.; Gaur, V.K.; Pandey, A. Production and Applications of Pullulan of the chapter. In Biomass, Biofuels, Biochemicals; Elsevier: Amsterdam, The Netherlands, 2021; pp. 165-221. [CrossRef]

113. Raus, R.A.; Nawawi, W.M.F.W.; Nasaruddin, R.R. Alginate and Alginate Composites for Biomedical Applications. Asian J. Pharm. Sci. 2020, 16, 280-306. [CrossRef]

114. Grøndahl, L.; Lawrie, G.; Anitha, A.; Shejwalkar, A. Applications of Alginate Biopolymer in Drug Delivery of the chapter. In Biointegration of Medical Implant Materials; Elsevier: Amsterdam, The Netherlands, 2020; pp. 375-403. [CrossRef]

115. Prajatelistia, E.; Sanandiya, N.D.; Nurrochman, A.; Marseli, F.; Choy, S.; Hwang, D.S. Biomimetic Janus Chitin Nanofiber Membrane for Potential Guided Bone Regeneration Application. Carbohydr. Polym. 2021, 251, 1-7. [CrossRef]

116. Verma, M.L.; Kumar, S.; Das, A.; Randhawa, J.S.; Chamundeeswari, M. Chitin and Chitosan-Based Support Materials for Enzyme Immobilization and Biotechnological Applications. Environ. Chem. Lett. 2020, 18, 315-323. [CrossRef]

117. Alnadari, F.; Xue, Y.; Zhou, L.; Hamed, Y.S.; Taha, M.; Foda, M.F. Immobilization of B-Glucosidase from Thermatoga Maritima on Chitin-Functionalized Magnetic Nanoparticle Via a Novel Thermostable Chitin-Binding Domain. Sci. Rep. 2020, 10, 1-12. [CrossRef]

118. Abdellatif, F.H.H.; Abdellatif, M.M. Bio-Based I-Carrageenan Aerogels as Efficient Adsorbents for Heavy Metal Ions and Acid Dye from Aqueous Solution. Cellulose 2020, 27, 441-453. [CrossRef] 
119. Ji, Y.; Wen, Y.; Wang, Z.; Zhang, S.; Guo, M. Eco-Friendly Fabrication of a Cost-Effective Cellulose Nanofiber-Based Aerogel for Multifunctional Applications in Cu (Ii) and Organic Pollutants Removal. J. Clean. Prod. 2020, 255, 1-11. [CrossRef]

120. Bui, N.-N.; Lind, M.L.; Hoek, E.M.; Mccutcheon, J.R. Electrospun Nanofiber Supported Thin Film Composite Membranes for Engineered Osmosis. J. Membr. Sci. 2011, 385, 10-19. [CrossRef]

121. Gebru, K.A.; Das, C. Removal of Chromium (Vi) Ions from Aqueous Solutions Using Amine-Impregnated TiO $\mathrm{Nanoparticles}_{2}$ Modified Cellulose Acetate Membranes. Chemosphere 2018, 191, 673-684. [CrossRef]

122. Li, X.; Tang, Y.; Cao, X.; Lu, D.; Luo, F.; Shao, W. Preparation and Evaluation of Orange Peel Cellulose Adsorbents for Effective Removal of Cadmium, Zinc, Cobalt and Nickel. Colloids Surf. A 2008, 317, 512-521. [CrossRef]

123. Jabur, A.R.; Abbas, L.K.; Moosa, S.A. Fabrication of Electrospun Chitosan/Nylon 6 Nanofibrous Membrane toward Metal Ions Removal and Antibacterial Effect. Adv. Mater. Sci. Eng. 2016, 2016, 1-10. [CrossRef]

124. Moharrami, P.; Motamedi, E. Application of Cellulose Nanocrystals Prepared from Agricultural Wastes for Synthesis of StarchBased Hydrogel Nanocomposites: Efficient and Selective Nanoadsorbent for Removal of Cationic Dyes from Water. Bioresour. Technol. 2020, 313, 1-10. [CrossRef] [PubMed]

125. Xie, X.; Zheng, Z.; Wang, X.; Lee Kaplan, D. Low-Density Silk Nanofibrous Aerogels: Fabrication and Applications in Air Filtration and Oil/Water Purification. ACS Nano 2021, 15, 1048-1058. [CrossRef] [PubMed]

126. Gore, P.M.; Naebe, M.; Wang, X.; Kandasubramanian, B. Silk Fibres Exhibiting Biodegradability \& Superhydrophobicity for Recovery of Petroleum Oils from Oily Wastewater. J. Hazard. Mater. 2020, 389, 121823. [CrossRef]

127. Chen, J.; Xiao, X.; Xu, Y.; Liu, J.; Lv, X. Fabrication of Hydrophilic and Underwater Superoleophobic Sio2/Silk Fibroin Coated Mesh for Oil/Water Separation. J. Environ. Chem. Eng. 2021, 9, 105085. [CrossRef]

128. Mia, M.S.; Yao, P.; Zhu, X.; Lei, X.; Xing, T.; Chen, G. Degradation of Textile Dyes from Aqueous Solution Using Tea-Polyphenol/Fe Loaded Waste Silk Fabrics as Fenton-Like Catalysts. RSC Adv. 2021, 11, 8290-8305. [CrossRef]

129. De Rossi, A.; Rigueto, C.V.; Dettmer, A.; Colla, L.M.; Piccin, J.S. Synthesis, Characterization, and Application of Saccharomyces Cerevisiae/Alginate Composites Beads for Adsorption of Heavy Metals. J. Environ. Chem. Eng. 2020, 8, 1-7. [CrossRef]

130. Huang, Y.; Sun, Y.; Liu, H. Fabrication of Chitin Nanofiber-PDMS Composite Aerogels from Pickering Emulsion Templates with Potential Application in Hydrophobic Organic Contaminant Removal. J. Hazard. Mater. 2021, 419, 1-15. [CrossRef] [PubMed]

131. Ahmad, N.; Sultana, S.; Khan, M.Z.; Sabir, S. Chitosan Based Nanocomposites as Efficient Adsorbents for Water Treatment of the chapter. In Modern Age Waste Water Problems; Mohammad, O., Mohammad, O.A., Mohammad, Z.K., Mohammad, S., Iqbal, M.I.I., Eds.; Springer Nature: Cham, Switzerland, 2020; pp. 69-83. [CrossRef]

132. Zhao, X.; Wu, Q.; Huang, C.; Wei, H.; Wang, R.; Wang, C. Highly Efficient Separation Membrane Based on Cellulose Acetate/Chitosan Fibrous Composite Substrate with Activated Carbon Functional Adsorption Layer. J. Chem. Technol. Biotechnol. 2021, 96, 672-679. [CrossRef]

133. Ray, P.; Singh, P.S.; Polisetti, V. Synthetic Polymeric Membranes for the Removal of Toxic Pollutants and Other Harmful Contaminants from Water of the chapter. In Removal of Toxic Pollutants through Microbiological and Tertiary Treatment; Elsevier: Amsterdam, The Netherlands, 2020; pp. 43-99. [CrossRef]

134. Saedi, S.; Shokri, M.; Rhim, J.-W. Preparation of Carrageenan-Based Nanocomposite Films Incorporated with Functionalized Halloysite Using Agnp and Sodium Dodecyl Sulfate. Food Hydrocoll. 2020, 106, 1-9. [CrossRef]

135. Razak, M.R.; Yusof, N.A.; Aris, A.Z.; Nasir, H.M.; Haron, M.J.; Ibrahim, N.A.; Johari, I.S.; Kamaruzaman, S. Phosphoric Acid Modified Kenaf Fiber (K-PA) as Green Adsorbent for the Removal of Copper (Ii) Ions Towards Industrial Waste Water Effluents. React. Funct. Polym. 2020, 147, 104-466. [CrossRef]

136. Pandiarajan, A.; Kamaraj, R.; Vasudevan, S.; Vasudevan, S. OPAC (Orange Peel Activated Carbon) Derived from Waste Orange Peel for the Adsorption of Chlorophenoxyacetic Acid Herbicides from Water: Adsorption Isotherm, Kinetic Modelling and Thermodynamic Studies. Bioresour. Technol. 2018, 261, 329-341. [CrossRef]

137. Peng, B.; Yao, Z.; Wang, X.; Crombeen, M.; Sweeney, D.G.; Tam, K.C. Cellulose-Based Materials in Wastewater Treatment of Petroleum Industry. Green Energy Environ. 2020, 5, 37-49. [CrossRef]

138. Janesch, J.; Jones, M.; Bacher, M.; Kontturi, E.; Bismarck, A.; Mautner, A. Mushroom-Derived Chitosan-Glucan Nanopaper Filters for the Treatment of Water. React. Funct. Polym. 2020, 146, 1-10. [CrossRef]

139. Abdellah, M.H.; Pérez-Manríquez, L.; Puspasari, T.; Scholes, C.A.; Kentish, S.E.; Peinemann, K.-V. A Catechin/Cellulose Composite Membrane for Organic Solvent Nanofiltration. J. Membr. Sci. 2018, 567, 139-145. [CrossRef]

140. Habibi, Y.; Lucia, L.A.; Rojas, O.J. Cellulose Nanocrystals: Chemistry, Self-Assembly, and Applications. Chem. Rev. 2010, 110, 3479-3500. [CrossRef]

141. Jamróz, E.; Kulawik, P.; Kopel, P. The Effect of Nanofillers on the Functional Properties of Biopolymer-Based Films: A Review. Polymers 2019, 11, 675. [CrossRef]

142. Heinze, T.; Rahn, K. Cellulose-P-Toluenesulfonates: A Valuable Intermediate in Cellulose Chemistry, Macromolecular Symposia; Hiithig \& Wepf Verlag: Zug, Germany, 1997; pp. 103-113.

143. Heinze, T.; Pfeifer, A.; Koschella, A.; Schaller, J.; Meister, F. Solvent-Free Synthesis of 6-Deoxy-6-( $\Omega$-Aminoalkyl) Amino Cellulose. J. Appl. Polym. Sci. 2016, 133, 1-7. [CrossRef]

144. Hu, Y.-J.; Wang, Y.; Huang, Y.-H.; Bian, J.; Li, M.-F.; Peng, F.; Sun, R.-C. Benzoxazine Enhanced Amino Cellulose-Based Composite Films: Preparation, Proposed Mechanism, and Improved Performance. Carbohydr. Polym. 2019, 222, 1-8. [CrossRef] [PubMed] 
145. Kalia, S.; Dufresne, A.; Cherian, B.M.; Kaith, B.; Avérous, L.; Njuguna, J.; Nassiopoulos, E. Cellulose-Based Bio-and Nanocomposites: A Review. Int. J. Polym. Sci. 2011, 2011, 1-36. [CrossRef]

146. Liebert, T. Cellulose Solvents-Remarkable History, Bright Future of the chapter. In Cellulose Solvents: For Analysis, Shaping and Chemical Modification; ACS Publications: Washington, DC, USA, 2010; pp. 3-54. [CrossRef]

147. Gu, H.; Gao, X.; Zhang, H.; Chen, K.; Peng, L. Fabrication and Characterization of Cellulose Nanoparticles from Maize Stalk Pith Via Ultrasonic-Mediated Cationic Etherification. Ultrason. Sonochem. 2019, 66, 1-10. [CrossRef]

148. Qian, R.; Tang, A.; Chen, G. Tempo-Mediated Oxidation of Cellulose and Preparation of Cellulose Nanofibrils. J. Biobased Mater. Bioenergry 2011, 5, 253-257. [CrossRef]

149. Thakur, V.K.; Voicu, S.I. Recent Advances in Cellulose and Chitosan Based Membranes for Water Purification: A Concise Review. Carbohydr. Polym. 2016, 146, 148-165. [CrossRef] [PubMed]

150. Musarurwa, H.; Tavengwa, N.T. Application of Carboxymethyl Polysaccharides as Bio-Sorbents for the Sequestration of Heavy Metals in Aquatic Environments. Carbohydr. Polym. 2019, 237, 1-14. [CrossRef]

151. Khajavian, M.; Shahsavarifar, S.; Salehi, E.; Vatanpour, V.; Masteri-Farahani, M.; Ghaffari, F.; Tabatabaei, S.A. EthylenediamineFunctionalized Zif-8 for Modification of Chitosan-Based Membrane Adsorbents: Batch Adsorption and Molecular Dynamic Simulation. Chem. Eng. Res. Des. 2021, 175, 131-145. [CrossRef]

152. Yin, X.; Tang, S.; Yong, Q.; Zhang, X.; Catchmark, J.M. Oriented 2d Metal Organic Framework Coating on Bacterial Cellulose for Nitrobenzene Removal from Water by Filtration. Sep. Purif. Technol. 2021, 276, 1-7. [CrossRef]

153. He, X.; Du, M.; Li, H.; Zhou, T. Removal of Direct Dyes from Aqueous Solution by Oxidized Starch Cross-Linked Chitosan/Silica Hybrid Membrane. Int. J. Biol. Macro. 2016, 82, 174-181. [CrossRef]

154. Topuz, F.; Holtzl, T.; Szekely, G. Scavenging Organic Micropollutants from Water with Nanofibrous Hypercrosslinked Cyclodextrin Membranes Derived from Green Resources. Chem. Eng. J. 2021, 419, 1-12. [CrossRef]

155. Khalil, A.M.; Schäfer, A.I. Cross-Linked B-Cyclodextrin Nanofiber Composite Membrane for Steroid Hormone Micropollutant Removal from Water. J. Membr. Sci. 2021, 618, 1-12. [CrossRef]

156. Siddiqui, M.R.H.; Adil, S.; Assal, M.; Ali, R.; Al-Warthan, A. Synthesis and Characterization of Silver Oxide and Silver Chloride Nanoparticles with High Thermal Stability. Asian J. Chem. 2013, 25, 3405-3409. [CrossRef]

157. Jain, S.; Bhanjana, G.; Heydarifard, S.; Dilbaghi, N.; Nazhad, M.M.; Kumar, V.; Kim, K.-H.; Kumar, S. Enhanced Antibacterial Profile of Nanoparticle Impregnated Cellulose Foam Filter Paper for Drinking Water Filtration. Carbohydr. Polym. 2018, 202, 219-226. [CrossRef]

158. Fan, G.; Du, B.; Zhou, J.; Yu, W.; Chen, Z.; Yang, S. Stable $\mathrm{Ag}_{2} \mathrm{O} / \mathrm{g}-\mathrm{C}_{3} \mathrm{~N}_{4}$ pn Heterojunction Photocatalysts for Efficient Inactivation of Harmful Algae under Visible Light. Appl. Catal. B 2020, 265, 1-12. [CrossRef]

159. Rong, X.; Qiu, F.; Jiang, Z.; Rong, J.; Pan, J.; Zhang, T.; Yang, D. Preparation of Ternary Combined Zno-Ag $\mathrm{Z}_{2} \mathrm{O} / \mathrm{Porous} \mathrm{g-C}_{3} \mathrm{~N}_{4}$ Composite Photocatalyst and Enhanced Visible-Light Photocatalytic Activity for Degradation of Ciprofloxacin. Chem. Eng. Res. Des. 2016, 111, 253-261. [CrossRef]

160. Nath, M.R.; Ahmed, A.N.; Gafur, M.A.; Miah, M.Y.; Bhattacharjee, S. ZnO Nanoparticles Preparation from Spent Zinc-Carbon Dry Cell Batteries: Studies on Structural, Morphological and Optical Properties. J. Asian Cerm. Soc. 2018, 6, 262-270. [CrossRef]

161. Alswata, A.A.; Ahmad, M.B.; Al-Hada, N.M.; Kamari, H.M.; Hussein, M.Z.B.; Ibrahim, N.A. Preparation of Zeolite/Zinc Oxide Nanocomposites for Toxic Metals Removal from Water. Results Phys. 2017, 7, 723-731. [CrossRef]

162. Chan, Y.Y.; Pang, Y.L.; Lim, S.; Chong, W.C. Facile Green Synthesis of ZnO Nanoparticles Using Natural-Based Materials: Properties, Mechanism, Surface Modification and Application. J. Environ. Chem. Eng. 2021, 9, 1-27. [CrossRef]

163. Abdorreza, M.N.; Cheng, L.; Karim, A. Effects of Plasticizers on Thermal Properties and Heat Sealability of Sago Starch Films. Food Hydrocoll. 2011, 25, 56-60. [CrossRef]

164. Jost, V.; Kobsik, K.; Schmid, M.; Noller, K. Influence of Plasticiser on the Barrier, Mechanical and Grease Resistance Properties of Alginate Cast Films. Carbohydr. Polym. 2014, 110, 309-319. [CrossRef] [PubMed]

165. Han, J.-C.; Zhu, Y.-K.; Wang, L.-F.; Mu, Y.; Feng, G.-G.; Liu, K.-Q.; Tong, C.-H.; Yu, Z.-X. Modification of Regenerated Cellulose Ultrafiltration Membranes with Multi-Walled Carbon Nanotubes for Enhanced Antifouling Ability: Field Test and Mechanism Study. Sci. Total Environ. 2021, 780, 146657. [CrossRef] [PubMed]

166. Ju, S.; Zhang, F.; Duan, J.; Jiang, J. Characterization of Bacterial Cellulose Composite Films Incorporated with Bulk Chitosan and Chitosan Nanoparticles: A Comparative Study. Carbohydr. Polym. 2020, 237, 1-8. [CrossRef]

167. Xie, J.; Huang, L.; Wang, R.; Ye, S.; Song, X. Novel Visible Light-Responsive Graphene Oxide/Bi2wo6/Starch Composite Membrane for Efficient Degradation of Ethylene. Carbohydr. Polym. 2020, 246, 1-11. [CrossRef]

168. Abdelhameed, R.M.; Abdel-Gawad, H.; Elshahat, M.; Emam, H.E. Cu-BTC@ Cotton Composite: Design and Removal of Ethion Insecticide from Water. RSC Adv. 2016, 6, 1-10. [CrossRef]

169. Abdelhameed, R.M.; Abdel-Gawad, H.; Emam, H.E. Macroporous Cu-MOF@ Cellulose Acetate Membrane Serviceable in Selective Removal of Dimethoate Pesticide from Wastewater. J. Environ. Chem. Eng. 2021, 9, 1-10. [CrossRef]

170. Garba, Z.N.; Zhou, W.; Lawan, I.; Zhang, M.; Yuan, Z. Enhanced Removal of Prometryn Using Copper Modified Microcrystalline Cellulose (Cu-Mcc): Optimization, Isotherm, Kinetics and Regeneration Studies. Cellulose 2019, 26, 1-18. [CrossRef]

171. Wittmar, A.; Thierfeld, H.; Köcher, S.; Ulbricht, M. Routes Towards Catalytically Active $\mathrm{TiO}_{2}$ Doped Porous Cellulose. RSC Adv. 2015, 5, 35866-35873. [CrossRef] 
172. De Guzman, M.R.; Andra, C.K.A.; Ang, M.B.M.Y.; Dizon, G.V.C.; Caparanga, A.R.; Huang, S.-H.; Lee, K.-R. Increased Performance and Antifouling of Mixed-Matrix Membranes of Cellulose Acetate with Hydrophilic Nanoparticles of Polydopamine-Sulfobetaine Methacrylate for Oil-Water Separation. J. Membr. Sci. 2021, 620, 1-16. [CrossRef]

173. Dodero, A.; Scarfi, S.; Mirata, S.; Sionkowska, A.; Vicini, S.; Alloisio, M.; Castellano, M. Effect of Crosslinking Type on the Physical-Chemical Properties and Biocompatibility of Chitosan-Based Electrospun Membranes. Polymers 2021, 13, 831. [CrossRef]

174. Liu, J.; Liu, D.; Liu, S.; Li, Z.; Wei, X.; Lin, S.; Guo, M. Preparation and Characterization of Sulfated Cellulose Nanocrystalline and Its Composite Membrane for Removal of Tetracycline Hydrochloride in Water. Energy Environ. Mater. 2020, 3, 209-215. [CrossRef]

175. Li, W.; Li, T.; Li, G.; An, L.; Li, F.; Zhang, Z. Electrospun H4siw12o40/Cellulose Acetate Composite Nanofibrous Membrane for Photocatalytic Degradation of Tetracycline and Methyl Orange with Different Mechanism. Carbohydr. Polym. 2017, 168, 153-162. [CrossRef] [PubMed]

176. Shi, Z.; Zhang, Y.; Shen, X.; Duoerkun, G.; Zhu, B.; Zhang, L.; Li, M.; Chen, Z. Fabrication of g- $\mathrm{C}_{3} \mathrm{~N}_{4} /$ BioBr Heterojunctions on Carbon Fibers as Weaveable Photocatalyst for Degrading Tetracycline Hydrochloride under Visible Light. Chem. Eng. J. 2020, 386, 124010. [CrossRef]

177. Galiano, F.; Briceño, K.; Marino, T.; Molino, A.; Christensen, K.V.; Figoli, A. Advances in Biopolymer-Based Membrane Preparation and Applications. J. Membr. Sci. 2018, 564, 562-586. [CrossRef]

178. Khaless, K.; Achiou, B.; Boulif, R.; Benhida, R. Recycling of Spent Reverse Osmosis Membranes for Second Use in the Clarification of Wet-Process Phosphoric Acid. Minerals 2021, 11, 637. [CrossRef]

179. Dai, R.; Han, H.; Wang, T.; Li, J.; Tang, C.Y.; Wang, Z. Fouling Is the Beginning: Upcycling Biopolymer-Fouled Substrates for Fabricating High-Permeance Thin-Film Composite Polyamide Membranes. Green Chem. 2021, 23, 1013-1025. [CrossRef]

180. Niaounakis, M. Biopolymers: Reuse, Recycling, and Disposal, 1st ed.; William Andrew: Norwich, NY, USA, 2013 ; ISBN 9781455731459.

181. Fenyvesi, E.; Gruiz, K.; Verstichel, S.; De Wilde, B.; Leitgib, L.; Csabai, K.; Szaniszlo, N. Biodegradation of Cyclodextrins in Soil. Chemosphere 2005, 60, 1001-1008. [CrossRef]

182. Chong, M.N.; Jin, B.; Chow, C.W.; Saint, C. Recent Developments in Photocatalytic Water Treatment Technology: A Review. Water Res. 2010, 44, 2997-3027. [CrossRef] 